Przegląd Narodowościowy / Review of Nationalities • nr 7/2017 • World of Slavs / Świat Słowian

\title{
Geopolitical consequences of Rusophilism of Carpathian Rusyns
}

Geopolityczne konsekwencje rusofilstwa Rusinów Karpackich

Keywords: Carpatho-Rusyns, Lemkos, Rusophilism, Russia, Geopolitics

The concepts from the title are so ambiguous and controversial that they can become the basis for extensive discussion. However, as if that was not enough, the author intends to complicate this whole situation even more by extending meanings, especially on the level of understanding of the concept of Rusophilism, and then narrowing the scope of research to the case of the Carpathian Rusyns. Although even this term may be difficult and imprecise. At least the goal is fairly simple in its premise, to show how the development of a certain ideology, thought has influenced the shaping of identity and politics in a certain region of the world, but also what influence it has and may have. The first term that will be operationalized is the latter term of the title. By the Carpathian Rusyns we will understand the people living in the Carpathians, speaking the Eastern Slavonic language, inhabiting former Galicia, mainly its eastern part and Bukovina. After World War II, the popu-
Słowa kluczowe: Rusini Karpaccy, Łemkowie, rusofilstwo, Rosja, geopolityka

Pojęcia z samego tytułu są na tyle wieloznaczne i kontrowersyjne, że mogą stać się podstawą do szerokiej dyskusji. By jednak tego było mało, autor całą tę sytuację zamierza jeszcze bardziej skomplikować przez poszerzenie znaczeń, zwłaszcza na płaszczyźnie rozumienia pojęcia rusofilstwa, by następnie zawęzić zakres badań do casusu Rusinów Karpackich. Choć i ten termin może okazać się trudny i nieprecyzyjny. Przynajmniej cel jest dość prosty w swym założeniu - pokazać, jak rozwój pewnej ideologii, myśli nie tylko miał wpływ na kształtowanie się tożsamości i polityki w pewnym rejonie świata, ale i jaki wpływ ma i może nadal mieć. Pierwszym pojęciem, które zostanie zoperacjonalizowane, jest ostatnie z tytułu. Przez Rusinów Karpackich rozumieć będziemy ludność zamieszkującą Karpaty, mówiącą językiem wschodniosłowiańskim, zamieszkującą niegdysiejszą Galicję, głównie jej wschodnią część i Bukowinę. Po II wojnie światowej ludność ta znalazła

\footnotetext{
* Correspondence address: Instytut Bezpieczeństwa i Edukacji Obywatelskiej, Uniwersytet Pedagogiczny im. KEN w Krakowie, ul. Podchorążych 2, 30-084 Kraków, e-mail: pmazur.up@wp.pl.
} 
lation was within the borders of Poland, the Ukrainian Soviet Socialist Republic (and thus the USSR, and today Ukraine), Czechoslovakia (today the Slovak Republic), but also to a lesser degree in Hungary, Romania and even Vojvodina. The Polish group of this population is called the Lemkos, on the southern side of the Carpathians the Lamakas, and as a whole they are called Carpatho-Rusyns, Carpathian Rusyns, etc. The Lemkos and the inhabitants of the Ukrainian part of the Carpathians, i.e., the Subcarpathian region (especially from the perspective of Kiev, which we will say much yet) ${ }^{1}$.

Yet, defining geopolitics is much more difficult. Of course, the first thing to do is to take a stance on the essence of the subject and its relevance to science. There is a very popular belief in the lack of scientific quality of this activity because it does not explain the intricacies of this world, it does not even have the capacity for predictability, and theories often do not fit into reality. Leszek Moczulski, to whose book we will be referring, defines geopolitics as the use of history, geography and many other sciences to explain the spatiotemporal relationships between states and their groups ${ }^{2}$. This interdisciplinarity causes that it is a very intriguing activity on the one hand, and thus fashionable, but at the same time very difficult. The overlapping

${ }^{1}$ See more about the origins of the ethnonyms of this group: H. Duć-Fajfer, Literatura łemkowska $w$ drugiej połowie XIX w i na początku XX wieku, Kraków 2001, p. 16; W. Strumynśkyj, Nazwa ljudej i kraju, [in:] Łemkiwszczyna. Zemla - ljudy - istoryja - kultura, edit. B. Struminsky, part 1, New YorkParis-Sydney-Toronto, pp. 11-22.

2 L. Moczulski, Geopolityka. Potęga w czasie i przestrzeni, Warszawa 1999, p. 30. się w granicach Polski, Ukraińskiej Socjalistycznej Republiki Radzieckiej (i tym samym ZSRR, a dzisiaj Ukrainy), Czechosłowacji (dzisiaj Republika Słowacka), ale także w mniejszym stopniu na Węgrzech, Rumunii, a nawet Wojwodiny. Polska grupa tej ludności zwana jest Łemkami, po południowej stronie Karpat Łamakami, a jako całość nazywani są Karpato-Rusinami, Rusinami Karpackimi itd. Szczególnie interesującymi będą dla nas Łemkowie i mieszkańcy ukraińskiej części Karpat, czyli regionu przykarpackiego (patrząc z perspektywy Kijowa, a o tych perspektywach jeszcze dużo powiemy) ${ }^{1}$.

Zdefiniowane geopolityki jest już znacznie trudniejsze. Pierwszym problemem jest oczywiście zajęcie stanowiska co do istoty przedmiotu i jego przydatności dla nauki. Istnieje bardzo popularne przekonanie o braku naukowości tego zajęcia, gdyż nie tłumaczy ono zawiłości tego świata, nie ma choćby zdolności predyktywności, a i teorie często nie przystają do rzeczywistości. Leszek Moczulski, do którego książki jeszcze będziemy się odwoływać, definiuje geopolitykę jak wykorzystanie geografii historii i wielu innych nauk do wyjaśnienia relacji czasoprzestrzennych, występujących między państwami i ich zgrupowaniami². Ta interdyscyplinarność powoduje, że z jednej strony jest to zajęcie bardzo intrygujące, stąd i modne, ale jed-

${ }^{1}$ Więcej na temat genezy etnonimów tej grupy np. w: H. Duć-Fajfer, Literatura łemkowska $w$ drugiej połowie XIX w i na początku XX wieku, Kraków 2001, s. 16; por. W. Strumynśkyj, Nazwa ljudej i kraju, [w:] Łemkiwszczyna. Zemla - ljudy - istoryja kultura, red. B. Struminsky, cz.1, Nowy Jork-ParyżSydney-Toronto, s. 11-22.

2 L. Moczulski, Geopolityka. Potęga w czasie i przestrzeni, Warszawa 1999, s. 30. 
of political science, economics, demography, and even natural sciences such as geography, creates very serious problems of methodological nature, but also the researcher is required to take into account so many factors that it may lead, additionally in the absence of his methodological theory, even to abuses. The latter has also become the cause of a certain odiousness of geopolitics, especially after World War II, when German geopoliticians were charged with servility towards Nazism and expansionism $^{3}$. To this day geopolitics has been perceived as a form of seeking alibi for the greed of imperialism. However, it has a direct impact on politics and, as such, is an interesting subject of research. It is difficult today to reject the influence of the geopolitical school represented by Henri Kissinger and Zbigniew Brzezinski on the behavior of the United States. Even after the collapse of the USSR it was still continued by the new generation, as it is seen in Madeleine Albright's politics (Brzezinski's PhD student $)^{4}$. This school ${ }^{5}$ assumed a fundamental premise, still taken by Haliford Mackinder and transformed by Nicholas Spykaman, about the need to master the area around Hartland, that is, generalizing the landlocked part of Eurasia and part of the Arctic Sea watershed. Anyone who is able to stop Hartland can give the world peace. This idea was also known in Russia

\footnotetext{
3 Such allegations were directed at Karl Haushofer and the Institute of Geopolitics in Munich (see: L. Moczulski, op. cit., p. 31, footnote 86).

4 See more: M.K. Albright, B. Woodward, Pani Sekretarz Stanu, Warszawa 2005.

5 See more about the US geostrategy and its implementation in politics: Z. Lach, J. Skrzyp, Geopolityka i geostrategia, Warszawa 2007, pp. 46-78.
}

nocześnie bardzo trudne. Nakładanie się na siebie politologii, ekonomii, demografii, a nawet nauk przyrodniczych jak geografii powoduje bardzo poważne problemy natury metodologicznej, ale też i wymaga od badacza brania pod uwagę tak wielu czynników, że prowadzić to może, dodatkowo przy braku własnej teorii metodologicznej, do przeoczeń czy nawet nadużyć. To ostatnie stało się też przyczyną pewnego odium geopolityki, zwłaszcza po II wojnie światowej, gdy zarzucano niemieckim geopolitykom służalczość wobec nazizmu i ekspansjonizmu ${ }^{3}$. Do dziś geopolityka jest postrzegana jako forma szukania alibi dla zachłanności imperializmów. Tymczasem ma ona bezpośredni wpływ na politykę i jako taka jest ciekawym przedmiotem badań. Trudno dzisiaj odmówić wpływu na postępowanie Stanów Zjednoczonych na skutek szkoły geopolitycznej reprezentowanej przez Henrego Kissingera i Zbigniewa Brzezińskiego, nawet po upadku ZSRR nadal była kontynuowania przez już nowe pokolenie, widać to choćby w polityce Madeleine Albright (doktorantki Brzezińskiego $)^{4}$. Szkoła ${ }^{5}$ ta wychodziła od pewnego fundamentalnego założenia, powziętego jeszcze przez Haliforda Mackindera, a przetworzonego przez Nicholasa Spykamana, o konieczności opanowania terenów dookoła Hartlandu, czyli generalizując części bezodpływo-

3 Takie zarzuty kierowano choćby wobec Karla Haushofera i monachijskiego Instytutu Geopolityki (zob. L. Moczulski, op. cit., s. 31, przyp. 86).

${ }^{4}$ Więcej: M.K. Albright, B. Woodward, Pani Sekretarz Stanu, Warszawa 2005.

${ }^{5}$ Więcej na temat amerykańskiej geostrategii i jej wykorzystania w polityce: Z. Lach, J. Skrzyp, Geopolityka i geostrategia, Warszawa 2007, s. 46-78. 
and gained much recognition. Firstly, because it can give you an understanding of US policy, especially after World War II. Secondly, Russia was de facto in the heart of Hartland, so this doctrine elevated Russia's importance to world order, but more importantly, it was in the centuries-long conviction of this meaning and the simultaneous danger of the West.

\section{Central Europe - a geopolitical pivot}

Geopolitics is also understood very narrowly as merely an attempt to understand the influence of geography (or geographic environment) on politics, including its extension in the form of war'. Then it can be treated as a sphere of strategic military use, also called geostrategy in this approach $^{7}$. Of course, in a broader sense, the geographic factor remains at the center of the issue as an invariant element around which variable systems of power are going on ${ }^{8}$. In this sense, Central Europe occupies a particularly prominent place in world politics, because here we are dealing with a few boundaries. Mackinder noted that the area between the Adriatic, Baltic and Black seas is a particularly important area, and the independent states of the area, called the Intermarium or the $\mathrm{ABC}$ zone (from the first letters of the seas),

\footnotetext{
${ }^{6}$ C. von Clausewitz, O wojnie, Kraków 2006.

7 L. Moczulski, op. cit., p. 78.

8 Ibidem, p. 75.
}

wej Euroazji i części zlewiska Morza Arktycznego. Ten kto jest w stanie Hartland powstrzymać, może zapewnić światu pokój. Idea ta znana była również w Rosji i zyskała spore uznanie. Po pierwsze dlatego, że dawać to może zrozumienie polityki Stanów Zjednoczonych, zwłaszcza po II wojnie światowej. Po drugie, to Rosja była de facto w sercu Hartlandu, więc doktryna ta podnosiła znaczenie Rosji dla porządku światowego, ale co ważniejsze wpisywała się w wielowiekowe przekonanie o tym znaczeniu i jednoczesnym zagrożeniu ze strony Zachodu.

\section{Europa Środkowa - sworzeń geopolityczny}

Geopolityka rozumiana jest również bardzo wąsko, jako jedynie próba zrozumienia wpływu geografii (czy dokładniej środowiska geograficznego) na politykę, w tym na jej przedłużenie w postaci wojny ${ }^{6}$, wtedy można traktować ją jako dziedzinę zajmującą się przestrzennymi aspektami wykorzystania strategicznych możliwości militarnych, inaczej zwana też w tym ujęciu geostrategią̧ ${ }^{7}$.Oczywiście w szerszym aspekcie czynnik geograficzny nadal pozostaje w centrum zagadnienia, jako element niezmienny, wokół którego zachodzą zmienne układy sił ${ }^{8} \mathrm{~W}$ takim rozumieniu Europa Środkowa zajmuje szczególnie istotne miejsce w polityce światowej, to tutaj bowiem mamy do czynienia z kilkoma granicami. Sam Mackinder zauważył, że rejon między morzami: Adriatykiem, Bałtykiem i Czarnym jest miejscem

\footnotetext{
6 C. von Clausewitz, O wojnie, Kraków 2006.

7 L. Moczulski, op. cit., s. 78.

8 Ibidem, s. 75.
} 
may be the buffer for possible aggression from Hartland'. History shows that Asia has had a major impact on Europe, but at the same time it is clear that Asia itself has never been strong enough to get Europe, only when it was able to cooperate with its periphery it constituted a major threat. The periphery is Central Europe and Germany is particularly important. The combination of German and Russian forces can cause political upheaval on a global scale. It is just enough to mention the end of the First World War. The United States joined it primarily because of the agreement between Germany and Russia, resulting in the so-called Treaty of Brest of 3 March 1918.

Seizing Central Europe has several meanings for Russia. First, it increases its potential and gives the opportunity to prepare an effective offensive, but it also has a geostrategic importance. Looking at the physical map we see that the area of present-day Poland is a gateway to the West, where the great Central European Plain (in Polish formerly Niż Środkowoeuropejski ${ }^{10}$ ) is situated. This is a very convenient place for a possible offensive to Europe. It is not surprising, therefore, that this was the direction of Russia's expansion, first in the $18^{\text {th }}$ century, then in the Bolshevik War of 1919 , and finally building there a block of socialist states after 1945. But the acqui-

9 H.J. Mackider, Democratic Ideals and reality, London-New York 1919, p. 154, cited from: L. Moczulski, op. cit., p. 17.

10 Protokół 48. posiedzenia Komisji Standaryzacji Nazw Geograficznych poza Granicami Rzeczypospolitej Polskiej, p. 5, za: http://ksng.gugik.gov.pl/ pliki/protokol_ksng/protokol ksng-48 posiedzenie.pdf [access on: 1.10.2016]. szczególnie ważnym, a niepodległe państwa tego rejonu, zwanego Międzymorzem lub strefą $\mathrm{ABC}$ (od pierwszych liter nazw mórz) mogą stanowić bufor dla ewentualnej agresji ze strony Hartlandu'. Historia pokazuje, że Azja miała zasadniczy wpływ na Europę, jednocześnie jednak widać wyraźnie, że sama Azja nigdy nie była na tyle silna, by Europę zdobyć, jedynie gdy była w stanie kooperować ze swoimi obrzeża$\mathrm{mi}$, to stanowiła istotne zagrożenie. Tymi obrzeżami jest właśnie Europa Środkowa, a szczególnie istotne są Niemcy. Połączenie siły niemieckiej i rosyjskiej może powodować zachwianie ładu politycznego w skali światowej. Wystarczy wspomnieć końcówkę I wojny światowej - Stany Zjednoczone włączyły się do niej przede wszystkim z powodu porozumienia Niemiec z Rosją, w wyniku tzw. traktatu brzeskiego z 3 marca $1918 \mathrm{r}$.

Opanowanie Europy Środkowej ma kilka znaczeń dla Rosji. Po pierwsze, jest zwiększeniem jej potencjału i daje możliwość przygotowania skutecznej ofensywy, ale ma też znaczenie geostrategiczne. Patrząc na mapę fizyczną, dostrzegamy, że teren dzisiejszej Polski stanowi swoistą bramę na Zachód, tu rozpościera się wielka Nizina Środkowoeuropejska (dawniej Niż Środkowoeuropejski ${ }^{10}$ ). Jest to bardzo dogodne miejsce do ewentualnej ofensywy na Europę. Nic zatem dziwnego, że

9 H.J. Mackider, Democratic Ideals and reality, London-New York 1919, s. 154, za: L. Moczulski, op. cit., s. 17.

10 Protokół 48. posiedzenia Komisji Standaryzacji Nazw Geograficznych poza Granicami Rzeczypospolitej Polskiej, s. 5, za: http://ksng.gugik.gov.pl/ pliki/protokol_ksng/protokol_ksng-48_posiedzenie.pdf [dostęp: 1.10.2016]. 
sition of Poland itself does not solve the problem of Russia, because it borders with strong Germany and possible exploration is very difficult. Hence, Russia must gain more space in the rest of Central Europe. One of the reasons is access to the sea and further the ocean. The separation of the continental empire from the ocean, de facto, separates it from the possibility of further development towards a real empire. The world has been ruled by those who ruled the seas: Ancient Rome, Spain, England and finally USA. Meanwhile, while Russia remained on its ethnic lands, this access was very difficult. In fact, at the beginning, it was only the Baltic Sea and in a very narrow part. Moreover, the Baltic Sea is a closed sea. Hence the expansion towards Crimea and the founded Novorossiya with access to the Black Sea. This is also, however, a sea closed by the Bosphorus Strait, which also had to determine the policy of Russia.

The beginning of Russia's departure from Hartland is half of the $18^{\text {th }}$ century. Russian troops reach Berlin in 1759 and 1760, making the Republic of Poland dependent on Russia, breaking down among others the Confederation of Bar. They then directed their expansion towards the Black Sea, defeating Turkey (1768-1774). Catherine II Great played an important role consistently striving for her goal of getting to the Balkans, occupying the Central European Plain and ultimately capturing Istanbul. Even by choosing the names of their grandchildren, she revealed her goals directly. Konstantin was to become the ruler of Constantinople (Istanbul), and Alexander was to be the Tsar of Russia formed był to kierunek ekspansji Rosji, najpierw w wieku XVIII, a potem w ramach wojny bolszewickiej od 1919 r. i wreszcie zbudowania tam bloku państw socjalistycznych po 1945 r. Ale samo zdobycie Polski i tak nie rozwiązuje problemu Rosji, gdyż tutaj graniczy z silnymi Niemcami i ewentualna eksploracja jest bardzo trudna. Stąd też Rosja musi zdobyć większą przestrzeń w dalszej części Europy Środkowej. Jednym $z$ powodów jest dostęp do morza i dalej oceanu - odseparowanie kontynentalnego mocarstwa od oceanu de facto odcina go od możliwości dalszego rozwoju w kierunku rzeczywistego imperium, światem rządzili przecież ci, którzy rządzili na morzach: Starożytny Rzym, Hiszpania, Anglia, wreszcie USA. Tymczasem Rosja, pozostając na swoich etnicznych ziemiach, ten dostęp miała bardzo utrudniony. W rzeczywistości na początku był to tylko Bałtyk i to w bardzo wąskim zakresie, do tego Bałtyk będący morzem zamkniętym. Stąd też ekspansja w kierunku Krymu i założona Noworosja z dostępem do Morza Czarnego. To również jednak jest morzem zamkniętym przez Cieśniny Bosforskie, co też musiało zdeterminować politykę Rosji.

Początek wyjścia Rosji z Hartlandu to połowa XVIII w., wojska rosyjskie osiągają Berlin w 1759 i 1760, uzależniają od siebie Rzeczpospolitą, gromiąc m.in. konfederację barską. Następnie kierują swoją ekspansję w kierunku Morza Czarnego, pokonują Turcję (1768-1774). Olbrzymią rolę odegrała tutaj caryca Katarzyna II Wielka, konsekwentnie dążąca do swojego celu, jakim było wyjście na Bałkany, zawładnięcie Niziną Środkowoeuropejską 
as a result of great conquests. At the turn of the eighteenth and nineteenth centuries the expansion was continued, the Commonwealth was seized, the Swedish threat was diminished (1808) and thus Russia settled better on the shores of the Baltic and defeated Turkey (1792 and 1812), Russian troops even reached Italy (17981799), but most of all Napoleon was defeated, and Tsar Alexander graciously did not burn Paris (1814). Russia thus conquered a large part of the Central European Plain, but could not conquer all of Central Europe, thus encountering the German element in the form of Prussia and Vienna. After these events, Russia weakened and its importance in Europe gradually declined, the most important was the defeat in the Crimean War, which made it more difficult to conquer and control the Balkans and the Black Sea. These failures were made up for expansion in Central Asia and the Far East. The end was the war with Japan (1904-1905) and the establishment of a border with China, while new conquests had a very important impact on the ethnic and civilizational situation of Russia. The next wave of Hartland expansion occurred only during World War II. This was also possible thanks to a significant increase in the industrial potential achieved through the slave industrialization.

This weakening after the first phase of expansion, which dates back to at least 1825 , i.e. the rebellion of the Decembrists and the rule of the new Tsar Nicholas, as evidenced by the Polish uprising in November, did not change Russia's interests and geopolitical plans. The state still had the goal to take control over Intermari- i docelowo zdobycie Stambułu. Nawet dobierając imiona swoich wnuków, wyjawiła swoje cele w sposób bezpośredni. Konstanty miał zostać panem Konstantynopola (Stambułu), a Aleksander carem Rosji powstałej w wyniku wielkich podbojów. $\mathrm{Na}$ przełomie wieku XVIII i XIX kontynuowano ekspansję, zajęto Rzeczpospolitą, oddalono zagrożenie szwedzkie (1808) i tym samym usadowiono się lepiej na brzegach Bałtyku, pokonano Turcję (1792 i 1812), wojska rosyjskie dotarły nawet do Włoch (1798-1799), ale przede wszystkim rozbito Napoleona, a car Aleksander łaskawie nie spalił Paryża (1814). Tym samym Rosja podbiła znaczną część Niziny Środkowoeuropejskiej, nie mogła jednak podbić całej Europy Środkowej, natrafiając tutaj na żywioł niemiecki, w postaci Prus i Wiednia. Po tych wydarzeniach Rosja osłabła i jej znaczenie w Europie stopniowo spadało, najważniejsza był porażka w wojnie krymskiej, co znacznie utrudniło opanowanie i kontrolowanie Bałkanów i basenu Morza Czarnego. Te niepowodzenia powetowano sobie ekspansją w Azji Środkowej i Dalekim Wschodzie. Kresem okazała się wojna z Japonią (1904-1905) i ustanowienie granicy z Chinami, jednocześnie nowe podboje miały bardzo ważny wpływ na sytuację etniczną i cywilizacyjną Rosji. Do kolejnej fali ekspansji Hartlandu doszło dopiero w czasie II wojny światowej. Było to też możliwe dzięki znacznemu zwiększeniu potencjału przemysłowego osiągniętego dzięki katorżniczej industrializacji.

To osłabienie po pierwszej fazie ekspansji, które możemy datować od przynajmniej 1825 r., czyli buntu dekabrystów 
um and securing the Bosphorus. In this place the opponents were, theoretically friendly, Austria and above all Turkey. The southern part of Intermarium is the Danube-Balkan macro-region, and its central part is the extensive Pannonian Basin. The Pannonian Basin is the best-developed defensive bastion in Europe ${ }^{11}$, and there are just a few entrances to it. From the north, the Vienna Gate, the lowering of the area between the Carpathians and the Alps, in the center of which the Danube flows. The Moravian Gate, a pass between the Beskids and the Sudetes, leads to it. The second entrance is through the Moldavian Gate, which stretches from the Black Sea to the Carpathian arch, leads to the lowlands of Romania and Bulgaria, but getting to the Pannonian basin you still have to break through the Iron Gate, the area between the Carpathians and the Balkans (Serbian Carpathians), or the Wallachian Plain. Finally, the last entrance is the Kosovar Gate leading from Thessaloniki to Belgrade. There are also several other entrances, from the North they are the Dukla, Uzhok, and Yablunytskyj passes, and even further the Brasov Depression (Transylvania). The Pannonian Basin resembles a peculiar bastion surrounded by natural fortifications made by the mountains, and what is more important, forming a whole defense system. The only possibility of further expansion is first of all gaining control over strategically important passes. The seizing of this basin offers tremendous opportunities for expansion in the Balkans, to Istanbul, but above all

11 L. Moczulski, op. cit., p. 169. i rządów nowego cara - Mikołaja, czego najlepszym dowodem było polskie powstanie listopadowe, nie zmieniło jednak interesów i planów geopolitycznych Rosji. Ta nadal za cel stawiała sobie zapanowanie nad Międzymorzem i zabezpieczenie Bosforu. Tutaj przeciwnikami była, teoretycznie przyjazna, Austria i przede wszystkim Turcja. Południowa część Międzymorza to makroregion dunajsko-bałkański, a jego centralną częścią jest obszerny basen panoński. Basen panoński to najlepiej ukształtowany naturalnie bastion obronny w Europie ${ }^{11}$, wejść do niego jest zaledwie kilka. Od północy wiedzie Brama Wiedeńska, obniżenie terenu między Karpatami i Alpami, środkiem którego przepływa Dunaj, prowadzi do niej Brama Morawska, czyli przełęcz między Beskidami i Sudetami. Drugie wejście wiedzie przez Bramę Mołdawską, czyli odcinek od Morza Czarnego do łuku Karpat, daje on wejście na niziny Rumunii i Bulgarii, ale do samego basenu panońskiego należy jeszcze sforsować Żelazną Bramę, teren między Karpatami a Bałkanami (Góry Wschodnioserbskie), czyli Nizinę Wołoską. Wreszcie ostatnim wejściem jest Brama Kosowska prowadząca z Salonik do Belgradu. Ponadto jest jeszcze kilka innych wejść: od północy to Przełęcze Dukielska, Użocka i Tatarska, a jeszcze dalej Kotlina Braszowska (Siedmiogród). Basen panoński przypomina swoisty bastion otoczony naturalnymi umocnieniami w postaci gór, co jeszcze ważniejsze tworzącymi cały system, na którym można oprzeć obronę. Jedyną możliwością dalszej ekspansji jest

11 L. Moczulski, op. cit., s. 169. 
through the Vienna Gate and the Czech Republic it opens the way to the West, and even Talleyrand claimed that the ruler of Prague controls Europe ${ }^{12}$.

\section{Carpathians the gate to the world}

As a result of the resolutions of the Vienna Congress, Russia did not receive any of these sensitive geostrategic passes. Thanks to the wide arch of the Carpathians, Austria was protected very well from Russia. Also, Moldova was under Turkish rule, then Bulgarian or Romanian, and only Russia's Bessarabia bordered with the Moldavian Gate, getting to the Danube. The Russians were well aware of the importance of these places, Galicia was especially important. Equally distant from the Baltic Sea and Black Sea, there is a trans-dividing junction in Lvov. The Baltic and Black Sea catchment areas and drainage basins of the Vistula, Dniester, Dnieper and even the Danube are connected there. All this causes Lvov to become the center of natural routes leading to the Baltic Sea (Przemysl, Brest), Czarne (Kamianets, Chernivtsi) to the east (Kiev), west (Kraków) and finally to the Danube via Uzhgorod or Mukachevo. Taking control over the interchange is therefore of strategic importance. The road to the Pannonian Basin leads through well-accessible Carpathian basins. The first road leads through the Uzhok Pass ( $852 \mathrm{~m}$ above sea level) towards the

12 Ibidem, p. 174. przede wszystkim zdobycie kontroli nad strategicznie ważnymi przejściami. Zdobycie tego basenu daje olbrzymie możliwości ekspansji na Bałkany, Stambuł, ale przede wszystkim przez Bramę Wiedeńską i Czechy otwierające drogę na Zachód, a już nawet Talleyrand stwierdził, że kto włada Czeską Pragą, to włada Europą ${ }^{12}$.

\section{Karpaty bramą na świat}

W wyniku postanowień Kongresu Wiedeńskiego Rosja nie otrzymała żadnego $\mathrm{z}$ tych newralgicznych geostrategicznie przejść. Austria dzięki szerokiemu łukowi Karpat w bardzo dogodny sposób była zasłonięta przed Rosją. Również Mołdawia była pod panowaniem to Turcji, to później Bułgarii czy Rumunii, a Rosja jedynie swą Besarabią graniczyła z Bramą Mołdawską, dochodząc do linii Dunaju. Rosjanie zdawali sobie znakomicie sprawę ze znaczenia tych miejsc, szczególnie ważna była Galicja. W równej odległości od Morza Bałtyckiego i Czarnego znajduje się transdziałowe węzłowisko lwowskie. Łączą się tam zlewiska bałtyckie i czarnomorskie oraz dorzecza: Wisły, Dniestru, Dniepru, a nawet Dunaju. Wszystko to powoduje, że Lwów staje się centrum naturalnych dróg prowadzących nad Morze Bałtyckie (Przemyśl, Brześć), Czarne (Kamieniec, Czerniowce), na wschód (Kijów), zachód (Kraków) i wreszcie nad Dunaj przez Użhorod lub Mukaczewo. Opanowanie tego węzła ma zatem znaczenie strategiczne. Droga w stronę basenu panońskiego wiedzie przez dobrze dostępne kotliny karpackie. Pierwsza droga wie-

12 Ibidem, s. 174. 
river Tisza, or through Łupków Pass (640 $\mathrm{m}$ above sea level, from the 1887 railway connection) or the Verecke Pass. The second route is the route through Przemyśl, then the Lupków Pass or the Verecke Pass, or even further towards the the Low Beskids and the Dukla Pass (504 m over sea level) and a network of smaller passes in the region. Seizing Lvov and then Przemysl gives you the opportunity to take the direction of the Carpathian Pass. To illustrate how important the passes are it is enough to notice that from the Dukla Pass to Kosice it is only $120 \mathrm{~km}$, and then the straight road to Eger, Miskolc, Budapest and the Balkans or Vienna. The second (though more difficult to achieve) Łupków Pass (or Komancza Pass) leads to Humenne, and this is about $70 \mathrm{~km}$.

The Russians first appeared in this region during the pacification of the Bar Confederation. The fighting took place in 1770, General Ivan Drawicz smashed Polish troops commanded, among others, by Kazimierz Pulaski at Grab, Izby and Wysowa in the Lemkivshchyna region ${ }^{13}$. But more important was the appearance of the Russians more than half a century later. Then (1849) Field Marshal Ivan Paskevich hastened to relieve the Habsburgs in Hungary, passing through the Dukla Pass and Bardejov, Presov. At that time, the Russians saw with their own eyes the potential of this region. Despite this apparent proximity, the passage was not easy, the

${ }^{13}$ W. Konopczyński, Kazimierz Pułaski, Kraków 1931; M. Śliwa, Zaginiony obóz konfederatów barskich, "Almanach Muszyny" 2007, pp. 95-102; В. Хыляк, Повісти і оповіданя, Том 1, Шьбеничний Bepx, Gorlice-Kraków 2013. dzie przez Przełęcz Użocką (852 m n.p.m.) w kierunku rzeki Cisy lub poprzez Przełęcz Łupkowską (640 m n.p.m. - od 1887 r. połączenie kolejowe) czy Warecką. Drugą drogą jest trakt przez Przemyśl i następnie Przełęcz Łupkowską lub Warecką (tzw. Ruska Brama) lub jeszcze dalej w kierunku Beskidu Niskiego i Przełęcz Dukielską (504 m n.p.m.) oraz sieć pomniejszych przełęczy tego regionu. Opanowanie Lwowa i następnie Przemyśla daje możliwość obrania kierunku na Przełęcze Karpackie. By zobrazować, jak ważne są to przejścia, wystarczyć może fakt, że od Przełęczy Dukielskiej do Koszyc jest zaledwie 120 km, a dalej już prosta droga na Eger, Miszkolc, Budapeszt i Bałkany lub Wiedeń. Druga (choć trudniejsza do osiągnięcia) Przełęcz Łupkowska (czyli okolice Komańczy) wiedzie do Humenne, a to ok. $70 \mathrm{~km}$.

Rosjanie pierwszy raz w tym rejonie pojawili się jeszcze podczas pacyfikacji konfederacji barskiej. Do walk doszło w 1770 r., generał Iwan Drawicz rozbił wówczas oddziały polskie dowodzone m.in. przez Kazimierza Pułaskiego pod Grabiem, Izbami i Wysową na Łemkowszczyźnie ${ }^{13}$. Ale istotniejsze było pojawienie się Rosjan w ponad pół wieku później. Wówczas to (1849) feldmarszałek Iwan Paskiewicz śpieszył z pomocą Habsburgom na Węgry, przejeżdżając przez Przełęcz Dukielską i dalej Bardejów, Preszów (Presov). Wtedy to Rosjanie naocznie przekonali się o potencjale, jakie dawało opanowanie tego rejonu. Mimo

13 W. Konopczyński, Kazimierz Pułaski, Kraków 1931; M. Śliwa, Zaginiony obóz konfederatów barskich, „Almanach Muszyny” 2007, s. 95102; В. Хыляк, Повісти і оповіданя, Том 1: Шььбеничний Верx, Gorlice-Kraków 2013. 
Dukla Pass seemed the most comfortable. The route from Vistula to the Dunajec River Valley and to the Biala River from the north, the route from the east led through Lvov and Przemysl, and the infrastructure was very convenient. Austria, however, did not intend to facilitate this at all, so even the Przemysl fortress ${ }^{14}$, but above all even in the lowest Low Beskids, where the average relative height is sometimes only $300 \mathrm{~m}$, and the average height is 600 to $700 \mathrm{~m}$ over sea level, but still these are the mountains ${ }^{15}$. They were very good for fortified frontiers, especially thanks to the formation of parallel chains, which allowed for the creation of a specific chain of fortified positions that supported each other. Art of war knows the notion of "political accessibility of the theater", i.e. the attitude of the population to the fighting armies $^{16}$. It is nothing but the favorability, or at least the neutrality of the population living in the area of warfare, which concerns the whole theater of action, not just the place of direct military clashes, but also the supply network, for example, freedom of movement and logistical security. Activities in hostile environments are more difficult, require more personal effort, and often involve asymmetric struggles, such as diversion from the unfavorable population. The Russians were well aware of their strategic goals and knew very well that

14 See more: T. Idzikowski, Twierdza Przemyśl: powstanie, rozwój, technologie, Krosno 2014.

15 A. Aksamitowski, Karpaty jako teren działań wojennych jesienia 1944 roku, [in:] Tędy szli... Operacja Karpacko-Dukielska - retrospekcja 60 lat później, edit. W. Wróblewski, Krosno 2004, pp. 58-59.

16 Z. Parucki, Geografia polityczna i wojenna, Warszawa 1979, p. 13. tej pozornej bliskości przejście wcale nie było proste, najdogodniejsza wydawała się Przełęcz Dukielska, od północy wiodła tam wprost od Wisły dolina rzeki Dunajec i dalej Białej, od wschodu droga wiodła przez Lwów i Przemyśl, infrastrukturalnie trasa bardzo dogodna. Austria jednak nie zamierzała wcale tej drogi ułatwiać, stąd choćby twierdza Przemyśl ${ }^{14}$, ale przede wszystkim nawet w najniższym Beskidzie Niskim, gdzie średnia wysokość względna to czasami ledwie $300 \mathrm{~m}$, a przeciętna wysokość to 600-700 m n.p.m., to jednak góry ${ }^{15}$. Nadawały się świetnie na umocnione rubieże, głównie dzięki ukształtowaniu $\mathrm{w}$ równoległe pasma, dzięki temu można było stworzyć swoisty łańcuch pozycji umocnionych, wspierających się wzajemnie. Sztuka wojenna zna pojęcie „politycznej dostępności teatru”, czyli stosunku ludności do walczących wojsk ${ }^{16}$. To nic innego jak przychylność lub przynajmniej neutralność ludności zamieszkującej rejon działań wojennych, dotyczy to całego teatru działań, czyli nie tylko samego miejsca bezpośrednich starć militarnych, ale również zaplecza, co zapewnia np. swobodę poruszania się, zabezpieczenia logistycznego. Działania na terenie całkowicie wrogo nastawionym są trudniejsze, wymagają większych nakładów osobowych, często dochodzi tam do walki asymetrycznej, czyli np. dywersji ze strony ludności nie-

14 Więcej: T. Idzikowski, Twierdza Przemyśl: powstanie, rozwój, technologie, Krosno 2014.

15 A. Aksamitowski, Karpaty jako teren działań wojennych jesienia 1944 roku, [w:] Tędy szli... Operacja Karpacko-Dukielska - retrospekcja 60 lat później, red. W. Wróblewski, Krosno 2004, s. 58-59.

16 Z. Parucki, Geografia polityczna $i$ wojenna, Warszawa 1979, s. 13. 
people there were very similar to them in language and even religion. This element could be used to secure "political accessibility", especially as these people were alienated in many ways by foreigners, and even hostile, especially in the relations between the Christian Balkans and the Muslim Turks.

\section{The Russian idea}

Already in the first words of this article an objection was made to the ambiguity of certain terms, among others, to $\mathrm{Ru}$ sophilism. So far, this term has not been discussed. It was chosen because of its popularity, as the article will focus mainly on the events of the turn of the nineteenth and the twentieth centuries, the choice is most correct. Nevertheless, with the contemporary commentary it can already raise our concerns. Therefore, other concepts are used for better defining the ideology or political thought ${ }^{17}$ that is being discussed here. The first such a "skeleton key" word is the concept of 'moskalofilstwo' and 'moskwofilstwo' (both mean: Rusophilism or Moscophilism). The first one is used by the Lemko scholar Jaroslaw Moklak ${ }^{18}$, to draw attention to the

\footnotetext{
17 See: A. Heywood, Ideologie polityczne. Wprowadzenie, Warszawa 2007, pp. 16-17.

18 For instance: J. Moklak, Łemkowszczyzna $w$ drugiej Rzeczpospolitej, zagadnienia polityczne i wyznaniowe, Kraków 1997, but C. Partacz also writes about Rusophilism, idem, Od Badeniego do Potockiego Stosunki polsko-ukraińskie w Galicji w latach 1888-1908, Toruń 1997.
}

przychylnej działaniom. Rosjanie doskonale znali swoje cele strategiczne i doskonale wiedzieli, że żyją tam ludzie do nich bardzo podobni, pod względem języka, a nawet religii. Ten element można było wykorzystać dla zapewnienia sobie „politycznej dostępności”, zwłaszcza że ludność ta zamieszkiwała państwa im obce pod wieloma względami, a nawet wrogie, zwłaszcza widoczne to było w relacjach pomiędzy chrześcijańskimi Słowianami Bałkanów i muzułmańskimi Turkami.

\section{Idea rosyjska}

Już w pierwszych słowach tego artykułu dokonano zastrzeżenia niejasności pewnych terminów, w tym i rusofilstwa, dotychczas nie był ten termin przedmiotem rozważań. Został wybrany ze względu na jego popularność - ponieważ mowa będzie tu głównie o wydarzeniach z przełomu XIX i XX w., dobór tego jest jak najbardziej poprawny. Niemniej przy czekającym nas komentarzu współczesnym może już budzić zastrzeżenia. Dlatego też pojawiają się inne terminy mające za zadanie lepsze dookreślenie ideologii czy też myśli politycznej ${ }^{17}$, o której tu jest mowa. Pierwszym takim „wytrychem” słownym jest pojęcie moskalofilstwa czy moskwofilstwa, tym pierwszym posługuje się choćby badacz Łemkowszczyzny Jarosław Moklak ${ }^{18}$. Ma to na celu zwrócenie uwagi na zasadni-

17 Por. A. Heywood, Ideologie polityczne. Wprowadzenie, Warszawa 2007, s. 16-17.

18 Np. J. Moklak, Łemkowszczyzna w drugiej Rzeczpospolitej, zagadnienia polityczne i wyznaniowe, Kraków 1997, ale o moskalofilstwie pisze też C. Partacz, Od Badeniego do Potockiego. Stosunki polsko-ukraińskie w Galicji w latach 1888-1908, Toruń 1997. 
principal author of this idea, Moscow, not even a nation, ethnic group, but a political project, imperialism ${ }^{19}$. The second term is quite a new concept of "Russian collective imperialism" 20 , in other words a collection of certain beliefs that differ in terms of certain assumptions, but generally constructing the notion of a wider Russian community consisting of various ethnic groups, but above all the three Rus nations (Belarusians, Ukrainians, Russians - the AllRus nation $)^{21}$. Finally, there is also a broad concept called the Russian Idea (written in capital letters), which is actually the same as the previous ones, but without the pejorative sound ${ }^{22}$.

The first significant idea was Moscow as "Third Rome", whose creator was Philotheus a monk from the monastery of Pskov, who in the sixteenth century recognized that after the fall of Constantinople the only heir of true Christianity and divine anointing was the prince of Moscow and his Orthodox people (Pan-Slavic movement $\left.{ }^{23}\right)$. Later, the movement put

19 See: A. Nowak. Od imperium do imperium: spojrzenia na historie Europy Wschodniej, Warszawa 2004; and idem, Rosja i Europa Wschodnia: "imperiologia" stosowana = Russia and Eastern Europe: applied imperiology, edit. A. Nowak, Kraków 2006.

20 R. Radzik, Rosyjski imperializm wspólnotowy. Trójjedyny naród ruski w badaniach socjologicznych, Lublin 2016.

21 A. Wierzbicki, Nacjonalizm i geopolityka w Europie Wschodniej, [in:] Geopolityka w stosunkach polsko-rosyjskich, edit. S. Bieleń, A. Skrzypek, Warszawa 2012, pp. 97-98.

22 Moskalofistwo (Rusophilism, or Moscophilism) created from the word Moskal (citizen of the country of Moscow), the word used colloquially may have such a negative meaning in Poland.

23 See more: M. Romanowska, Stowianofile i staroobrzędowcy. Próba interpretacji, "Studia z Dziejów Rosji i Europy Środkowo-Wschodniej”, Warszawa 2008, vol. 42, pp.61-74; A. Walicki, W kręgu czego autora tej koncepcji, Moskwy, czyli nawet nie tyle narodu, grupy etnicznej, ile pewnego projektu politycznego, imperiali$\mathrm{zmu}^{19}$. Drugim określeniem jest dość nowe pojęcie „rosyjskiego imperializmu wspólnotowego" ${ }^{20}$, czyli zbiór pewnych różnych przekonań różniących się co do pewnych założeń, ale w zasadzie konstruujący pojęcie szerszej wspólnoty rosyjskiej, w skład której wchodzą różne etnicznie grupy, lecz przede wszystkim wszystkie trzy narody ruskie (Białorusini, Ukraińcy, Rosjanie naród ogólnoruski) ${ }^{21}$. Wreszcie jest równie szeroka koncepcja zwana Ideą Rosyjską (pisaną wielkimi literami), właściwie taka sama co poprzednie tylko bez pejoratywnego wydźwięku ${ }^{22}$.

Pierwszą istotną ideą była Moskwa jako „Trzeci Rzym”, twórcą był mnich z pskowskiego monasteru Filoteusz, który w XVI w. uznał, że po upadku Konstantynopola jedynym spadkobiercą prawdziwego chrześcijaństwa i boskiego pomazaństwa jest książę moskiewski i jego prawosławny lud (ruch pansłowiański²3).

19 Por. A. Nowak, Od imperium do imperium: spojrzenia na historię Europy Wschodniej, Warszawa 2004; oraz idem, Rosja i Europa Wschodnia: „imperiologia" stosowana = Russia and Eastern Europe: applied „imperiology”, red. A. Nowak, Kraków 2006.

20 R. Radzik, Rosyjski imperializm wspólnotowy. Trójjedyny naród ruski w badaniach socjologicznych, Lublin 2016.

21 A. Wierzbicki, Nacjonalizm i geopolityka w Europie Wschodniej, [w:] Geopolityka w stosunkach polsko-rosyjskich, red. S. Bieleń, A. Skrzypek, Warszawa 2012, s. 97-98.

22 Moskalofistwo utworzone od słowa Moskal, może mieć w Polsce taki wydźwięk, tak pisał o zaborcach choćby Adam Mickiewicz, słowo używane potocznie głównie miało znaczenie negatywne.

23 Więcej: M. Romanowska, Słowianofile i staroobrzędowcy. Próba interpretacji, „Studia z Dziejów Rosji i Europy Środkowo-Wschodniej”, Warszawa 2008, t. 42, s. 61-74; A. Walicki, W kregu konserwa- 
a greater emphasis on the people, accusing the elites of "infecting" themselves with the West, especially after the reign of Peter $\mathrm{I}^{24}$. This idea involves two important geopolitical issues. First, there is the sense of justification and the necessity of Western expansion (messianism), hence the notion of "collecting the Rus lands" (at least from the reign of Ivan III the Terrible, 1462-1505), i.e., the recovery of possession from times of Kievan Rus. The religious dimension is very important here, which is obviously understandable because of the subordination of the church to the ruler (tsar). Another very important element is the feeling of a siege, the West, the Latin people are apostates of the legitimate faith, whose purpose is to destroy Moscow and Orthodoxy beginning with the struggle of Alexander Nevsky. These assumptions make the Russians have a different culture and religion than the West, that is only true, it must be saved and then carried forward. One of the obstacles is Poland, which since the $15^{\text {th }}$ century has been competing with Russia (understand Moscow), is Catholic (Western) and it is done in Ruthenia (the former Duchy of the Rurik dynasty), it also makes Poles traitors ${ }^{25}$. These two assumptions, the besieged fortress and the historical messianism will be the basis of all subsequent ideas.

The first pretty consistent set of the concepts was Slavophilism, a movement that

konserwatywnej utopii. Struktura i przemiany rosyjskiego słowianofilstwa, Warszawa 1964.

24 See more: D. Romanowski, Trzeci Rzym, Rozwój rosyjskiej idei imperialnej, Kraków 2013, pp. 18 and following.

25 See: A. Walicki, Rosja, katolicyzm i sprawa polska, Warszawa 2002, p. 104.
Później ten ruch położył większy nacisk na lud, zarzucając elitom „zarażenie” się Zachodem, zwłaszcza po okresie rządów Piotra $\mathrm{I}^{24}$. Z tą ideą wiążą się dwie ważne geopolityczne kwestie, po pierwsze poczucie usprawiedliwienia i konieczności ekspansji w kierunku zachodnim (mesjanizm), stąd też pojęcie „zbierania ziem ruskich” (przynajmniej od rządów Iwana III Groźnego, 1462-1505), czyli odzyskania stanu posiadania z czasów Rusi Kijowskiej. Bardzo istotny jest tu wymiar religijny, co jest oczywiście zrozumiałe ze względu na podporządkowanie Cerkwi władcy (carowi). Drugim bardzo ważnym elementem jest poczucie oblężenia. Zachód, łacinnicy to odstępcy od prawowitej wiary, których celem jest zniszczenie Moskwy i prawosławia, począwszy od walk Aleksandra Newskiego. Te założenia powodują, że Rosjanie mają inną kulturę i religię niż Zachód, ta jedynie jest prawdziwa, należy ją ocalić i następnie zanieść dalej. Jedną z przeszkód jest Polska, która od wieku XV konkuruje z Rosją (czytaj Moskwą), jest katolicka (Zachodnia) i dokonuje się to na terenie Rusi (dawne księstwa Rurykowiczów), to też czyni Polaków zdrajcami sprawy ${ }^{25}$. Te dwa założenia, oblężonej twierdzy i mesjanizmu dziejowego, będą podstawą wszystkich kolejnych idei.

Pierwszym w miarę spójnym zbiorem koncepcji było słowianofilstwo, ruch wywodzący się o dziwo głównie z Niemiec. Zapoczątkował go Johann Gottfried Her-

tywnej utopii. Struktura i przemiany rosyjskiego słowianofilstwa, Warszawa 1964.

24 Więcej: D. Romanowski, Trzeci Rzym, Rozwój rosyjskiej idei imperialnej, Kraków 2013, s. 18 i n.

25 Por. A. Walicki, Rosja, katolicyzm i sprawa polska, Warszawa 2002, s. 104. 
originated surprisingly from Germany. It was initiated by Johan Gottfried Herder interested in the cultural diversity and purity of culture preserved among the people (volk) including the Slavs ${ }^{26}$. Later on, these premises were developed by the school of German idealists (Johann Gottlieb Fichte, Frederick Schelling, Georg Wilhelm Friedrich Hegel). Over time, this ideology evolved and went beyond just the enchantment of the Slavonic, and to the conviction that the truth preserved in the people, purity determines the Slavs to a certain historical mission, this is where Pan-Slavism appears. Interestingly, some of the artists were "traitors" of the Slavs, i.e. Poles, Stanisław Staszic $^{27}$ and Kazimierz Brodziński. Andrzej Walicki writes so rightly:

The nineteenth-century pro-Russian PanSlavism - not a faint idea of cultural "Slavic reciprocity", but a political program of PanSlavism - was born in Poland, much earlier than in Russia ${ }^{28}$.

Although the precursor was Croat, Juraj Križanič ${ }^{29}$ (also known as Yuriy Krizhanich or Iurii Krizhanich), priest and theologist. In 1646 he went to Russia, where out of 18 years, he spent 15 in ex-

26 A.D. Smith, Nacjonalizm. Teoria, ideologia, historia, Warszawa 2007, p. 86.

27 Especially in the book Ród ludzki, S. Staszic, Ród ludzki: wersja brulionowa po raz pierwszy ogłoszona drukiem według zachowanego rękopisu, Vol. 1, Warszawa 1959; See more: T. Matlęgiewicz, Program słowiański Stanisława Staszica po postanowieniach kongresu wiedeńskiego, "Przegląd Nauk Historycznych" 2011, R. 10, No. 1, pp. 187-204, E. Kołodziejczyk, Słowianofilstwo Warszawskiego Towarzystwa Przyjaciół Nauk (1800-1832), "Świat Słowiański" 1909, Vol. 58, No. 9, p. 207.

28 A. Walicki, Idea narodu w polskiej myśli oświeceniowej, Warszawa 2000, p. 80.

29 See: M. Helcer. Historia Imperium Rosyjskiego, Warszawa 2000, pp. 285-290. der zainteresowany różnorodnością kulturową i czystością kultury zachowanej wśród ludu (volk), w tym u Słowian ${ }^{26}$, potem te założenia rozwijała szkoła idealistów niemieckich (Johann Gottlieb Fichte, Fryderyk Schelling, Jerzy Wilhelm Fryderyk Hegel). Z czasem ideologia ta ewoluowała i poszła dalej niż tylko do zauroczenia Słowiańszczyzną, a do przekonania, że zachowana w ludzie prawda, czystość determinuje Słowian do pewnej misji dziejowej, tu pojawia się już panslawizm. Co ciekawe, jednymi z twórców byli „zdrajcy” Słowian, czyli Polacy, choćby Stanisław Staszic ${ }^{27}$ czy Kazimierz Brodziński. Andrzej Walicki tak słusznie pisze:

Dziewiętnastowieczny prorosyjski panslawizm - nie mglista idea kulturalnej „wzajemności słowiańskiej”, lecz polityczny program panslawizmu - zrodził się więc w Polsce, i to znacznie wcześniej niż w samej Rosji ${ }^{28}$.

Choć tak naprawdę prekursorem był Chorwat, Juryj Kryżanicz (Juraj Križanič $)^{29}$, ksiądz i teolog. W 1646 r. wyjechał do Rosji, gdzie z 18 lat 15 przebywał na zesłaniu w Tobolsku. Pojęcia panslawizmu po raz pierwszy użył Czech J. Her-

26 A.D. Smith, Nacjonalizm. Teoria, ideologia, historia, Warszawa 2007, s. 86.

27 Zwłaszcza w książce Ród ludzki: S. Staszic, Ród ludzki: wersja brulionowa po raz pierwszy ogłoszona drukiem według zachowanego rękopisu, t. 1, Warszawa 1959; więcej: T. Matlęgiewicz, Program słowiański Stanisława Staszica po postanowieniach kongresu wiedeńskiego, „Przegląd Nauk Historycznych" 2011, R. 10, Nr 1, s. 187-204, E. Kołodziejczyk, Słowianofilstwo Warszawskiego Towarzystwa Przyjaciół Nauk (1800-1832), „Świat Słowiański” 1909, R. 58, nr 9, s. 207.

28 A. Walicki, Idea narodu w polskiej myśli oświeceniowej, Warszawa 2000, s. 80.

29 Zob. M. Helcer. Historia Imperium Rosyjskiego, Warszawa 2000, s. 285-290. 
ile in Tobolsk. The concept of Pan-Slavism was first used by Czech J. Herkel in $1826^{30}$. Pan-Slavism quickly turned into Russophilism. In other words, it was accepted that the unification of the Slavs, which was the only salvation for those oppressed by Turkey or Austria, could only take place under the Romanov dynasty rule and the authorities of Russia. We can include to the precursors of this stream such persons as gen. R.A. Fadieyev, N. Danilevsky, M. Bakun$i^{31}$, A. Herzen, M. Rajewski and M. Po$\operatorname{godin}^{32}$. The movement was not uniform, of course, e.g. local movements focused on the interests of small homelands, but derived from Slavophilism and even PanSlavism. In Galicia, this was the Old Russian movement ${ }^{33}$, in the Balkans the Illyrian movement (L. Gaj - c. 1835) and Yugoslavianism (J.J. Strosmayer) postulated the unification of the Southern Slavs. Within the Illyrian movement, we can distinguish the Great Moravian and the Greater Siberian movements. Naczevtanije was a counter-proposal of the Serbs to the Croatian

30 J. Herkel, Elementa universalis linguae Slavicae (Zaklady vseslovanskeho jazyka), Vienna 1826.

31 See: M.A. Bakunin, Pisma wybrane, vol. 1 and 2; wyboru dokonała, wstępem i przypisami opatrzyła H. Temkinowa; Warszawa 1965; A. Leśniewski, Bakunin a sprawy polskie $w$ okresie Wiosny Ludów i powstania styczniowego 1863 roku, Łódź-Wrocław 1962; See more: Bakunin Bibliography, http:// dwardmac.pitzer.edu/Anarchist_Archives/bakunin/ Bakuninbiblio.html [access on: 1.10.2016].

32 See: K.I. Arsenew, The statistical sketches of Russia, Edinburgh 1856.

33 See more: P.R. Magocsi, Old Ruthenianisam and Russophilism: A New Conceptual Framework for Analyzing National Ideologies in Late $19^{\text {th }}$ Century Eastern Galicia, [in:] Literature, Poetics, History, edit. P. Debreczeny, American Contributions to the Ninth International Congress of Slavists, Kiev 1983, Columbus 1983, pp. 305-324. kel w 1826 r. ${ }^{30}$ Panslawizm bardzo szybko przeistoczył się w rusofilizm, tzn. uznano, że zjednoczenie Słowian, które jest jedynym ratunkiem dla tych ciemiężonych przez Turcję czy Austrię, może odbyć się tylko pod berłem Romanowów i władztwem Rosji. Do prekursorów tego nurtu można zaliczyć: gen. R.A. Fadiejewa, N. Danilewskiego, M. Bakunina ${ }^{31}$, Al. Herzena, M. Rajewskiego i M. Pogodina ${ }^{32}$. Ruch nie był oczywiście jednorodny, można wyróżnić choćby ruchy lokalne, koncentrujące się na interesach małych ojczyzn, ale wywodzące się ze słowianofilstwa, a nawet panslawizmu. W Galicji był to ruch staroruski ${ }^{33}$, na Bałkanach iliryzm (L. Gaj - ok. 1835) i jugosławianizm (J.J. Strosmayer), który postulował zjednoczenie Słowian południowych. W obrębie iliryzmu można wyróżnić ruchy: wielkochorwacki i wielkoserbski. Naczevtanije było kontrpropozycją Serbów na chorwacki iliryzm (Ilia Gavasanin) - zjednoczenie ziem Serbów, Chorwatów, Bośni, Hercegowiny, Dalmacji i Czarnogóry w odrębne

30 J. Herkel, Elementa universalis linguae Slavicae (Zaklady v seslovanskeho jazyka), Vienna 1826.

${ }^{31}$ Por. M.A. Bakunin, Pisma wybrane, t. 1 i 2; wyboru dokonała, wstępem i przypisami opatrzyła H. Temkinowa; Warszawa 1965; A. Leśniewski, Bakunin a sprawy polskie w okresie Wiosny Ludów i powstania styczniowego 1863 roku, Łódź-Wrocław 1962; więcej: Bakunin Bibliography, http://dwardmac.pitzer.edu/Anarchist_Archives/bakunin/Bakuninbiblio.html [dostęp: 1.10.2016].

32 Por. K.I. Arsenew, The statistical sketches of Russia, Edinburgh 1856.

${ }^{33}$ Więcej: P.R. Magocsi, Old Ruthenianisam and Russophilism: A New Conceptual Framework for Analyzing National Ideologies in Late $19^{\text {th }}$ Century Eastern Galicia, [w:] Literature, Poetics, History, red. P. Debreczeny, American Contributions to the Ninth International Congress of Slavists, Kiev 1983, Columbus 1983, s. 305-324. 
Illyrian movement (Ilia Gavasanin) the unification of the lands of Serbs, Croats, Bosnia, Herzegovina, Dalmatia and Montenegro into separate independent states. The greatest influence of this ideology was in the Czech Republic and in Slovakia, where perhaps the most eminent representative Jan Kollar (1793-1852) worked $^{34}$.

Rusophilism over time, however, began to be dysfunctional. The first reason was the changes taking place within Russia itself, which with each subsequent conquest in Siberia, Central Asia, or the Caucasus became less and less Slavic and less and less European. Another reason was the new philosophy borrowed from Germany, or communism. Here, there was serious clash between the national liberation of the oppressed and the proletarian liberation. Paradoxically, communism, in the form of Marxism-Leninism, well adapted the fundamental assumptions of this movement, that is, the messianism and sense of the besieged fortress. Meanwhile the emigration on the same base, but this time leaving the ethnic foundation, created a new concept called Eurasianism. The main representatives of this school include: N. Trubetzkoy, P. Suwczyśnki, G. Florowski, P. Suwczyński, P. Sawicki. This first one defined the new doctrine as the rejection of European culture and the creation of its own original, non-rejecting Asian heritage, in this Genghis Khan ${ }^{35}$. However, this school was heterogeneous and plagued

${ }^{34}$ See: H. Wereszycki, Pod bertem Habsburgów. Zagadnienie narodowościowe, Kraków 1986, pp. 44-46.

35 Z. Brzeziński, Wielka szachownica. Główne cele polityki amerykańskiej, Warszawa 1998, p. 137. niepodległe państwa. Największe wpływy ideologia ta miała w Czechach i na Słowacji, gdzie działał jej bodaj najwybitniejszy przedstawiciel Jan Kollar (1793-1852) ${ }^{34}$.

Rusofilizm z czasem jednak zaczął być dysfunkcjonalny. Pierwszym powodem były zmiany zachodzące w obrębie samej Rosji, która z każdym kolejnym podbojem na Syberii czy Azji Środkowej, Kaukazie stawała się coraz to mniej słowiańska i coraz to mniej europejska. Kolejnym powodem była nowa filozofia zapożyczona z Niemiec, czyli komunizm. Tutaj doszło do poważnego zgrzytu pomiędzy narodowym wyzwoleniem uciśnionych a wyzwoleniem proletariackim. Paradoksalnie jednak komunizm, w postaci marksizmu-leninizmu, dobrze zaadaptował fundamentalne założenia tego ruchu, czyli mesjanizm i poczucie oblężonej twierdzy. Tymczasem emigracja na tej samej bazie, ale tym razem już odchodząc od fundamentu etnicznego, wykreowała nową koncepcję zwaną eurazizmem. Do głównych przedstawicieli tej szkoły możemy zaliczyć: N. Trubeckiego, P. Suwczyśnkiego, G. Florowskigo, P. Suwczyńskiego, P. Sawickiego. Ten pierwszy nową doktrynę zdefiniował jako odrzucenie kultury europejskiej i stworzenie własnej oryginalnej, nieodrzucającej spuścizny Azji, w tym Czingis-chana ${ }^{35}$. Szkoła ta była niejednorodna i szargana wieloma animozjami osobistymi, można jednak wyodrębnić pewne główne nurty, pierwszy okres od 1921 do 1928 r., drugi zaczynający się wyda-

34 Por. H. Wereszycki, Pod berłem Habsburgów. Zagadnienie narodowościowe, Kraków 1986, s. 44-46.

35 Z. Brzeziński, Wielka szachownica. Główne cele polityki amerykańskiej, Warszawa 1998, s. 137. 
with many personal animosities. However, one can distinguish some main streams, the first period from 1921 to 1928 , the second one starting with the magazine "Eurasia" and ending with the death of Trubetzkoy in 1938 and finally the revival of the school after $1991^{36}$. Perhaps the most outstanding representative of neo-Eurasianism is Aleksandr Dugin ${ }^{37}$, a philosopher, political scientist, geopolitical scholar, professor at the Moscow State University $(\mathrm{MGU})^{38}$. The current supporters of this stream are Aleksandr Solzhenitsyn, Eligaz Pozdniakov, Geydar Dzhemal, HozhAhmed Nukhaev, as well as politicians such as Gennady Zyuganov, Yevgeny Primakov, Vladimir Zhirinovsky, Aleksandr Mitrofanov and Natalya Narochnitskaya ${ }^{39}$.

As it can be seen all these movements have some common assumptions and objectives, therefore, it is possible to speak of the Russian Idea, that is, the synthesis of Tsarist autocracy, tsaropapism of Orthodoxy, Slavophilism, Pan-Slavism, Eurasianism or even Marxism-Leninism. The most important here is a conviction about the civilization mission of Russia ${ }^{40}$, but in this article, we will use the term "Rusophilism"

36 I. Massaka, Eurazjatyzm, $Z$ dziejów rosyjskiego misjonizmu, Wrocław 2001, pp. 37-43.

37 See more: B. Gołąbek, Lew Gumilow i Aleksander Dugin. O dwóch obliczach Eurazjatyzmu w Rosji po 1991 roku, Kraków 2012.

38 L. Sykulski, Rola paradygmatu geopolitycznego w rozwoju neoeurazjanizmu we współczesnej Rosji, [in:] Między historia, literatura a polityka, edit. T. Nodzyński, Częstochowa 2009, pp. 151 and following.

39 Ibidem, p. 160.

40 L. Moczulski, op. cit., pp. 514-515.

41 For the events of the turn of the nineteenth and twentieth centuries, it is most well-founded for niem czasopisma „Eurazja”, a zakończony śmiercią Trubeckiego (Trubeckoja) w 1938 r. i wreszcie odrodzenie się szkoły po $1991 \mathrm{r} .^{36}$ Bodaj najwybitniejszym przedstawicielem neoeurazjanizmu jest Aleksander Dugin ${ }^{37}$, filozof, politolog, geopolityk, profesor Moskiewskiego Uniwersytetu Państwowego (MGU) ${ }^{38}$. Do współczesnych zwolenników tego nurtu zaliczyć możemy: Aleksandra Sołżenicyna, Eligza Pozdniakowa, Gejdara Dżemala, Hoż-Ahmed Nuhajewa, a także polityków, takich jak Gienadij Ziuganow, Jewgienij Primakow, Władimir Żyrinowski, Aleksander Mitrofanow czy Natalia Narocznickaja ${ }^{39}$.

Jak widać, wszystkie te ruchy mają pewne wspólne założenia i cel, dlatego też można uznać za słuszne mówienie o Idei Rosyjskiej, czyli syntezie samodzierżawia, caropapizmu prawosławia, słowianofilstwa, panslawizmu, eurazizmu czy nawet marksizmu-leninizmu; na pierwszy plan wysuwa się tu przekonanie o misji cywilizacyjnej Rosji ${ }^{40}$, niemniej w tym artykule będziemy używać pojęcia rusofilzmu ${ }^{41}$.

${ }^{36}$ I. Massaka, Eurazjatyzm, $Z$ dziejów rosyjskiego misjonizmu, Wrocław 2001, s. 37-43.

37 Więcej: B. Gołąbek, Lew Gumilow i Aleksander Dugin. O dwóch obliczach Eurazjatyzmu w Rosji po 1991 roku, Kraków 2012.

${ }^{38}$ L. Sykulski, Rola paradygmatu geopolitycznego w rozwoju neoeurazjanizmu we wspótczesnej Rosji, [w:] Między historia, literaturą a polityka, red. T. Nodzyński, Częstochowa 2009, s. 151 i n.

39 Ibidem, s. 160.

${ }^{40}$ L. Moczulski, op. cit., s. 514-515.

${ }^{41}$ Dla wydarzeń z przełomu XIX i XX w. jest on jak najbardziej zasadny, dla obecnego ruchu ze względu na odwoływanie się przez jego ideologów do jego tradycji. 


\section{Rusophilism in the Carpathians}

It is difficult to say clearly when the Russophile movement appeared in the Carpathians and throughout Galicia. The first such signs can be found in the sixties of the nineteenth century, when Denis Zubrytsky (Zubryćkyj), an interesting co-creator of "The Ruthenian Trinity" 42 , intensified his activity. The beginnings of his interest in Russia can be traced back in the mid-thirties when he met Mikhail Pogodin. There is no doubt that his activity was also financially supported by Moscow, albeit on a small scale ${ }^{43}$. However, the emergence of Rusophilism has its geopolitical determinants. It is a period of consolidation of the Ukrainian movement in Dnieper Ukraine (mainly Kiev and Kharkov), the final result of which was the Ems Ukaz of 1876. Another issue is the defeat of the Austro-Hungarian Empire Battle of Königgrätz (Sadova) in 1866, the weakening of the Habsburgs, which the Poles utterly exploited for their interests, and the Ukrainians also wanted, but above all it gave Russia hope for a successful rivalry. Especially that after the defeat in the Crimean War (1853-1856) the Russian "Greek plan" for the time being was unworkable. The acquisition of the pre-frontier area of Hartland could therefore take place at the expense of Austria. At the same time, Russia

the present movement, because of the references of its ideologists to its tradition.

42 W. Mokry, "Ruska Trójca": karta z dziejów życia literackiego Ukrainców w Galicji w pierwszej połowie XIX wieku, Kraków 1997.

43 B. Wojtowicz-Huber, Ojcowie narodu. Duchowieństwa greckokatolickie w ruchu narodowym Rusinów galicyjskich (1867-1918), Warszawa 2008, p. 67.

\section{Rusofilstwo w Karpatach}

Trudno jednoznacznie określić, kiedy ruch rusofilski pojawił się w Karpatach i szerzej całej Galicji. Pierwsze takie oznaki możemy odnaleźć w latach 60. XIX w., gdy Denys Zubrzycki (Zubryćkyj), co ciekawe współtwórca „Ruskiej Trójcy” ${ }^{42}$, intensyfikował swoją działalność. Początków jego zainteresowania Rosją można szukać już w połowie lat 30., gdy poznał Michaiła Pogodina. Nie ulega wątpliwości, że jego działalność była wspierana również finansowo z Moskwy, choć raczej na niewielką skalę $^{43}$. Pojawienie się rusofilstwa ma jednak swoje uwarunkowania geopolityczne, jest to okres wzmacniania się ruchu ukraińskiego w Ukrainie Naddnieprzańskiej (głównie Kijów i Charków), czego efektem będzie ukaz emski z 1876 r. Kolejną kwestią jest porażka Austro-Węgier pod Sadową (1866), osłabienie Habsburgów, które bezwzględnie wykorzystali Polacy dla swoich interesów. Chcieli również Ukraińcy, ale przede wszystkim dało to Rosji nadzieję na udaną rywalizację. Tym bardziej, że po klęsce w wojnie krymskiej (1853-1856) jej „grecki plan” na razie był niewykonalny. Zdobycie przedpola Hartlandu mogło zatem odbyć się kosztem Austrii. Rosja mogła jednocześnie ustanowić przeciwwagę dla ruchu ukraińskiego, będącego dla Austrii korzystnym stąd też wspieranym u siebie, ale i podtrzymać imperialne nadzieje. „Kamieniem milo-

${ }^{42}$ W. Mokry, „Ruska Trójca”: karta z dziejów życia literackiego Ukraińców w Galicji w pierwszej połowie XIX wieku, Kraków 1997.

43 B. Wojtowicz-Huber, Ojcowie narodu. Duchowieństwa greckokatolickie w ruchu narodowym Rusinów galicyjskich (1867-1918), Warszawa 2008, s. 67. 
could set a counterweight to the Ukrainian movement, which was also favorable for Austria, and because of that supported at home too, but to support imperial hopes as well. The "milestone" for this movement was the political manifesto of the Greek Catholic priest, Ivan Naumovich of 8 August 1866 . He accused the Ruthenians of being excessively passive, especially in light of Austria's weakness, seeing a chance to avoid polonization due to rapprochement with Russia ${ }^{44}$. In 1870 the Ruthenian Council was established, which referred to the Supreme Ruthenian Council, which was active in 1848 . Its main press bodies were "Nauka" and "Słowo" Ukrainian movement continued to develop dynamically, thanks to the Poles' favor. The result was a conversion (also called schism) in Hniliczki. In 1882, the population of the village of Hniliczki Małe (near Ternopil) transformed into orthodoxy, and the authorities recognized it as a pro-Russian sabotage. On 12 June 1882, the trial was held, with the main accused being Fr. Naumovych and Adolf Dobranskyj, though it is known as Olga Hrabar's case. They were accused of treason, espionage in old fortifications in Zaleszczyki, but above all the desire to incorporate $\mathrm{Bu}$ covina, Galicia and Hungarian into Russia. Eventually, it ended with 8 months of imprisonment for Naumovych and smaller penalties for others. The Hungarian daily Pester Lloyd concluded: "neither Ado-

${ }^{44}$ J.-P. Himka, Religion and Nationality in Western Ukraine: The Greek Catholic Church and the Ruthenian National Movement in Galicia, 1867-1900; Montreal-Kingston-London 1999, pp. 24-26.

${ }^{45}$ C. Partacz, op. cit., p. 33. wym" dla tego ruchu był manifest polityczny księdza greckokatolickiego Iwana Naumowycza z 8 sierpnia 1866 r. Zarzucił on Rusinom zbytnią bierność, zwłaszcza w obliczu sytuacji słabnięcia Austrii, widział on szansę na uniknięcie polonizacji dzięki zbliżeniu z Rosją ${ }^{44}$. W 1870 r. powstała Ruska Rada, nawiązująca do działającej w 1848 r. Hołownej Rady Ruskiej, jej głównymi organami prasowymi były pisma: "Nauka” i "Słowo"45, mimo tego ruch ukraiński rozwijał się nadal dynamicznie, również dzięki przychylności Polaków. Efektem była konwersja (zwana też schizmą) w Hniliczkach. W 1882 r. ludność wsi Hniliczki Małe (koło Tarnopola) przeszła na prawosławie, władze uznały to za prorosyjską dywersję. 12 czerwca $1882 \mathrm{r}$. odbył się proces, głównym oskarżonym był ks. Naumowycz oraz Adolf Dobrjanśkyj, choć przeszedł on do historii jako sprawa Olgi Hrabar. Zarzucano im zdradę stanu, szpiegostwo w starych fortyfikacjach w Zaleszczykach, ale przede wszystkim chęć przyłączenia do Rosji Bukowiny, Galicji i Węgierskiej Rusi. Ostatecznie skończyło się na 8 miesiącach pozbawienia wolności dla Naumowycza i mniejszych karach dla pozostałych. Węgierski dziennik „Pester Lloyd” podsumował: „nie Adolf Dobrjanśkyj i Iwan Naumowycz sq oskarżeni $\mathrm{w}$ tym procesie, ale rząd moskiewski. Nie zwalnia to nas od czujności. Nie ma państw w Europie, które nie musiałoby strzec się przed Rosją"46 . Sprawa ta jed-

44 J.-P. Himka, Religion and Nationality in Western Ukraine: The Greek Catholic Church and the Ruthenian National Movement in Galicia, 1867-1900, Montreal-Kingston-Londyn 1999, s. 24-26.

45 C. Partacz, op. cit., s. 33.

46 Ibidem, s. 39. 
If Dobranskyj nor Ivan Naumovych are accused in this process, but the Moscow government. It does not release us from alertness. There are no states in Europe that would not have had to guard against Russia" ${ }^{\prime \prime}$. The case, however, was of great significance. Firstly, the Metropolitan of Ljubljana, Joseph Sembratovych, a Lemko lenient for the Russophile movement, the Basilian order was reformed, now was to take care of the spiritual condition of the Greek Catholics, but first of all the Poles, being afraid of sharing the fate of their compatriots from the Russian Partition, made a number of agreements with the Ukrainian movement (even the BadeniRomanchuk agreement of 1888).

The Russophile movement lost its position on the political scene until the early $20^{\text {th }}$ century. It was a bit different in the case of the Orthodox Church. Here we have another interesting thread of a specific religious geopolitics ${ }^{47}$. The Commonwealth was an area where two confessions - Orthodox and Latin (Roman Catholic) - collided. This was considered a real threat to the state, hence the idea of the Union of Brest (1596), which was also aimed at demolishing Moscow's arguments for further expansion (gathering the Ruthenian lands ${ }^{48}$. The direct link between secu-

46 Ibidem, p. 39.

47 Geopolitics of religion can be defined as a way of thinking about space, serving its ordering and symbolic-emotional evaluation using religion, from: A. Curanovič, Geopolityka religii w stosunkach polsko-rosyjskich, [in:] Geopolityka w stosunkach..., p. 124.

48 Samuel Huntington shows well this rupture "inherited" today by Ukraine, S. Huntington, Zderzenie cywilizacji i nowy kształt ładu światowego, Warszawa 1997, p. 243. nak miała wielkie znaczenie, po pierwsze zdymisjonowano metropolitę lwowskiego Josefa Sembratowicza, Łemka pobłażliwego dla ruchu rusofilskiego, zreformowano zakon Bazylianów, teraz mający dbać o „kondycję duchową" grekokatolików, ale przede wszystkim Polacy, obawiając się podzielenia losu rodaków z zaboru rosyjskiego, zawarli wiele porozumień $\mathrm{z}$ ruchem ukraińskim (choćby układ Badeni-Romańczuk z 1888 r.).

Ruchu rusofilski utracił swoją pozycję na scenie politycznej do pierwszych lat XX w. Trochę inaczej wyglądało to w przypadku Cerkwi. Tutaj mamy kolejny ciekawy wątek, swoistej geopolityki religijnej ${ }^{47}$. Rzeczpospolita była rejonem, gdzie dochodziło do zderzenia się dwóch konfesji - prawosławnej i łacińskiej (rzymskokatolickiej). Uznawano to za realne zagrożenie dla państwa, stąd też pomysł unii brzeskiej (1596), co miało też na celu wytrącenie Moskwie argumentów dla dalszej ekspansji (zbierania ruskich ziem) ${ }^{48}$. Bezpośrednie powiązanie władzy świeckiej i duchownej w Rosji dawało jej możliwość wykorzystania prawosławia jako narzędzia polityki. O ile administracyjnie Polska choć trochę oddaliła prawosławie od swoich ziem ${ }^{49}$, o tyle ludność ruska

47 Geopolitykę religii możemy zdefiniować jako sposób myślenia o przestrzeni, służący jej uporządkowaniu i symboliczno-emocjonalnej ewaluacji Z wykorzystaniem religii, za: A. Curanovič, Geopolityka religii $w$ stosunkach polsko-rosyjskich, [w:] Geopolityka w stosunkach..., s. 124.

48 To pęknięcie „odziedziczone” dziś przez Ukrainę świetnie pokazuje S. Huntington, Zderzenie cywilizacji i nowy kształt ładu światowego, Warszawa 1997, s. 243.

49 Przykładem takiej geopolityki religijnej było niszczenie cerkwi po 1918 r., a już symbolicznym zburzenie soboru Aleksandra Newskiego w War- 
lar and clerical power in Russia gave it the opportunity to use Orthodoxy as a tool of politics. While on the administration terms Poland slightly reduced Orthodoxy to its lands ${ }^{49}$, the Ruthenian population still felt somewhat Orthodox and did not see any special differences. Hence nobody was surprised by the pilgrimage to the Orthodox Pochayiv Lavra, or defining themselves in the liturgy with the word "Orthodox". Clergy was largely aware of the danger of polonization in the Greek Catholic rite, and for this reason there were many pro-Orthodox and pro-Russian sympathies. Such use of faith in politics was not used by Russia alone. In Carpathian Ruthenia there were also very strong Hungarian influences ${ }^{50}$, more Russian in Galicia, and seminars were often left by pro-Ukrainian youth. Rusophilism among the Carpathian Ruthenians, however, was not the result of only Russian agitation, but many factors overlapped. First of all, it was a poorly educated population with very conservative attitudes, which was a form of cultural selfdefense for centuries, so as not to become Polonized or Magyarization. Finally, the social structure had a significant impact on this, the elites were very few and were

49 An example of such religious geopolitics was the destruction of the Orthodox churches after 1918 and the already symbolic demolition of the Alexander Nevsky Cathedral in Warsaw. This, in turn, was a symbol of subordinating Warsaw for the Russians during the Partitions. To this day, Russians "mark" their territory, placing crosses, or shrines in the farthest regions of Arctic, such as the Kolguyev Island (see: A. Curanovič, op. cit., p. 134), in times of the USSR, perhaps "palaces of culture and science" had the same function.

50 B. Wójtowicz-Huber, op. cit., p. 175. nadal czuła się w pewien sposób prawosławna i nie dostrzegała specjalnych różnic. Nikogo zatem nie dziwily pielgrzymki do prawosławnej ławry w Poczajowie czy określanie siebie w liturgii słowem „prawosławni”. Kler w dużej mierze widział zagrożenie polonizacji w obrządku greckokatolickim, dlatego występowały u niego liczne sympatie proprawosławne, a siłą rzeczy prorosyjskie. Takie wykorzystywanie wiary do polityki nie było stosowane tylko przez samą Rosję. Na Zakarpaciu dodatkowo bardzo silne były wpływy węgierskie $^{50}$, w Galicji bardziej rosyjskie, do tego seminaria opuszczała często młodzież już proukraińska. Rusofilizm wśród Rusinów Karpackich nie był jednak wynikiem tylko agitacji rosyjskiej, nakładało się na to wiele czynników. Po pierwsze była to ludność słabo wykształcona, w postawach bardzo konserwatywna, co było formą kulturowej samoobrony przez wieki, by nie ulec polonizacji czy madziaryzacji. Wreszcie to struktura społeczna miała na to wielki wpływ, elity były bardzo nieliczne i do tego głównie związane z rodami księżowskimi, niezainteresowane rewolucją nacjonalistyczną ${ }^{51}$.

Na początku XX w. doszło do odrodzenia się ruchu rusofilskiego. W wymiarze

szawie, ten z kolei był dla Rosjan symbolem opanowania Warszawy w czasie zaborów. Do dziś Rosjanie „oznaczają” swoje terytorium, stawiając choćby krzyże czy kapliczki w najodleglejszych rejonach Arktyki, np. na wyspie Kołgujew (por. A. Curanovič, op. cit., s. 134), za czasów ZSRR być może taką funkcje pełniły „pałace kultury i nauki”.

50 B. Wójtowicz-Huber, op. cit., s. 175.

51 Więcej: P. Mazur, Sukcesu nurtu rusofilskiego i starorusińskiego wśród Łemków w kontekście teorii elit VilfrefoPareto, „Rocznik Ruskiej Bursy 2014”, Gorlice 2014, s. 85-100. 
mostly connected with priest families, not interested in the nationalist revolution ${ }^{51}$.

At the beginning of the twentieth century, the Russophile movement was reborn. In the political dimension, it by far radicalized. Deputy Dmytro Markov used the Russian language in the parliament and even demanded that it was recognized as an official national language ${ }^{52}$. On the other hand, the interesting phenomenon was the emergence of more "mission centers" of Orthodoxy and Rusophilism at the same time. We can point at least at three such centers: Cieląż (Sokalsk district), Załuch (Śniatycz district) and Grab (Lemkivshchyna) ${ }^{53}$. Particularly interesting is the question of Lemko, where Fr. Maksym Sandowycz, Lemko educated in Russia, was a priest. Equally important was Father Mychajło Jurczakewycz from the village of Czarne, fierce Russophile, social activist, Orthodox promoter and founder of educational organizations. "In this way, Father Jurczakewycz prepared the ground for taking over and seducing those peasants who having returned from America were permeated by the idea of Russian state and Orthodoxy" ${ }^{\text {"4 }}$. Conversions were facilitated by several factors, firstly Russian assistance (there were missionary education there), secondly the favor of the Polish conservative and nationalist parties (rul-

51 See more: P. Mazur, Sukcesu nurtu rusofilskiego i starorusińskiego wśród Łemków w kontekście teorii elit Vilfrefo Pareto, "Rocznik Ruskiej Bursy 2014”, Gorlice 2014, pp. 85-100.

52 C. Partacz, op. cit., p. 207, więcej: B. Wójtowicz-Huber, op. cit., pp. 66-68.

53 B. Wójtowicz-Huber, op. cit., p. 181.

54 CDIAL (Centralnyj derżawnyj istorycznyj archiw Ukrajiny u m. Lwowi), 146/4/122, s.n., from: B. Wójtowicz-Huber, op. cit., p. 187. politycznym zdecydowanie się on zradykalizował, poseł Dmytro Markow w parlamencie posługiwał się językiem rosyjskim, a nawet żądał uznania go za oficjalny język krajowy ${ }^{52}$. Natomiast ciekawym zjawiskiem było powstawanie kolejnych „ośrodków misyjnych” prawosławia i rusofilstwa zarazem. Możemy mówić przynajmniej o trzech takich ośrodkach: Cieląż (okręg Sokalski), Załucz (okręg Śniatycz) i Grab (Łemkowszczyzna) ${ }^{53}$. Szczególnie ciekawa jest kwestia Łemkowszczyzny, tutaj posługę pełnił ojciec Maksym Sandowycz, prawosławny pochodzenia łemkowskiego kształcony w Rosji. Osobą równie ważną był ksiądz Mychajło Jurczakewycz ze wsi Czarne, zagorzały rusofil, działacz społeczny, propagator prawosławia i założyciel organizacji oświatowych. „W ten sposób przygotował ksiądz Jurczakewycz grunt do opanowania i zbałamucenia u tych włościan, którzy wróciwszy z Ameryki przesiąkli ideą państwowości rosyjskiej i prawosławia" ${ }^{4}$. Konwersjom sprzyjało kilka czynników, po pierwsze pomoc Rosji (to tam byli kształcenie misjonarze), po drugie przychylność polskich partii konserwatywnych i narodowców (rządzących od 1908 r.), po trzecie nieudolna agitacja kościoła greckokatolickiego ${ }^{55}$, postępująca ukrainizacja cerkwi i obrządku, migracja powrotna z USA (często prze-

52 C. Partacz, op. cit., s. 207, więcej: B. Wójtowicz-Huber, op. cit., s. 66-68.

53 B. Wójtowicz-Huber, op. cit., s. 181.

54 CDIAL (Centralnyj derżawnyj istorycznyj archiw Ukrajiny u m. Lwowi), 146/4/122, NN, za: B. Wójtowicz-Huber, op. cit., s. 187.

55 Np. zakaz kształcenia alumnów rusofilów w Przemyślu, nałożony przez bp. Konstatyna Czechowycza w 1909 r. 
ing since 1908), thirdly the inadequate agitation of the Greek Catholic Church ${ }^{55}$, the progressive Ukrainianization of the church and rite, the return migration from the USA, and last but not least, ordinary local disputes (aversion to the Greek Catholic clergy for personal reasons).

The political situation, however, began to change drastically, the Polish authorities $^{56}$ began to take seriously the aggression of Russia, one of the first reactions was the eradication of the Russophile movement. In May 1914, arrests took place, the first ones already appeared in 1912 when then Maksym Sandowycz and another Orthodox priest Ignacy Hudyma were arrested. This was the second process of "schismatics", this time called the "Bendasiuk's process" 57 , but this time no treason was proven.

The First World War period is a series of persecutions of Russophiles. Not only the activists, but also ordinary people who were under a cloud were sent to camps in Thalerhof, Graz, Theresienstadt and $\mathrm{Mu}$ kacz. It is estimated that about ten thousand people were arrested, mainly from Bukovina and Lemkivshchyna ${ }^{58}$. Maksym

55 For example, the ban on the educating of the Russians in Przemysl, imposed by bishop. Konstantin Czechowicz in 1909.

56 Polish in the ethnic sense.

57 See more: M. Bołtryk, Sąd nad świętym Maksymem, "Przegląd Prawosławny" 2004, No 7, A. Rydzanicz, Na wierność narodowi, "Przegląd Prawosławny”, No. 10 (220) Białystok 2003, also on-line: http://www.przegladprawoslawny.pl/articles. php?id_n=482\&id=8 [access on: 1.05.2016].

${ }_{58}$ P. Stefanowski, Łemkowie w Talerhofie, "Magury'82”, Warszawa 1982, pp. 41-48; T.A. Olszański, Krótko o Talerhofie, "Magury '82", Warszawa 1982, pp. 49-56. To commemorate Talerhof "Talerhofskyj Almanach" (“Talerhowski Almanach") is issued, http://www.ukrstor.com/talergof/ [access on: 1.10.2016]. chodzili na prawosławie), wreszcie zwykłe zatargi o charakterze lokalnym (niechęć do kleru greckokatolickiego z przyczyn osobistych).

Sytuacja polityczna jednak zaczęła się drastycznie zmieniać, władze polskie ${ }^{56} \mathrm{za}-$ częły poważnie brać pod uwagę agresję Rosji, jedną z pierwszych reakcji było skasowanie ruchu rusofilskiego. W maju $1914 \mathrm{r}$. doszło do aresztowań, pierwsze odbyły się już w 1912 r., pojmano wówczas Maksyma Sandowycza i innego księdza prawosławnego Ignacego Hudymę. Tak doszło do drugiego procesu „schizmatyków”, tym razem zwanego „procesem Bendasiuka”, ale i tym razem nie udowodniono zdrady stanu.

Okres I wojny światowej to seria prześladowań rusofilów. Nie tylko działacze, ale i zwykli ludzie, na których padł cień podejrzenia, byli wysyłani do obozów w Thalerhofie, Grazu, Theresienstadt i Mukaczu, łącznie ocenia się, że zniewolono około dziesięciu tysięcy ludzi, głównie z Bukowiny i Łemkowszczyzny ${ }^{58}$. Maksym Sandowycz został rozstrzelany bez sądu 6 września 1914 r. Przypuszcza się, że w pierwszych miesiącach wojny w $\mathrm{Ga}$ licji i Bukowinie rozstrzelano około ty-

56 Polskie oczywiście w sensie etnicznym.

57 Więcej: M. Bołtryk, Są nad świętym Maksymem, „Przegląd Prawosławny” 2004, nr 7; A. Rydzanicz, Na wierność narodowi, „Przegląd Prawosławny”, nr 10 (220) Białystok 2003, również on-line: http://www.przegladprawoslawny.pl/articles. php?id_n=482\&id=8 [dostęp: 1.05.2016].

58 P. Stefanowski, Łemkowie w Talerhofie, „Magury '82", Warszawa 1982, s. 41-48; T.A. Olszański, Krótko o Talerhofie, „Magury '82”, Warszawa 1982, s. 49-56. Dla upamiętnienia Talerhofu wydawany jest „Talerhofskyj Almanach” („Talerhowski Almanach”), http://www.ukrstor.com/talergof/ [dostęp: 1.10.2016]. 
Sandowycz was shot without trial on 6 September 1914. It is believed that in the first months of the war in Galicia and Bukovina, about one thousand civilians were shot. In addition, there were arbitrary murders carried out by soldiers (especially the Hungarians were brutal), for example, 30 people in Kuźmin (Cuzmin), hanging of more than 70 in Turka, finally the massacre of convoy of prisoners by Hungarian soldiers and a crowd in the streets of Przemyśl. In the massacre of 15 August 1914, only two persons of 46 prisoners survived ${ }^{59}$. All this happened in the sense of "Russian betrayal", which was to explain the enormous advances of Russian troops in Galicia and quick reaching the ridge of the Carpathians in this the Dukla Pass ${ }^{60}$.

From 4 September 1916 to 17 February 1917, the third great Russophile process was underway in Vienna. There were 22 defendants in the court, including 10 from Western Galicia (Lemkivshchyna), 9 from the Eastern Galicia and 3 from Bukovina. 16 or them were sentenced to the capital punishment, and they were not executed only because of the intercession of Tsar Nicholas II. The sentenced were accused of disseminating the Russophile idea and seeking to break Galicia, Bukovina and Transcarpathia from Austria ${ }^{61}$.

59 T.A. Olszański, Austriackie represje w Galicji i obóz w Thalerhofie, http://www.stowarzyszenielemkow.pl/new/modules/publisher/item.php?itemi$\mathrm{d}=100$ \&lang=polish [access on: 1.10.2016].

${ }^{60}$ A. Walc, Militarne i polityczne znaczenie Operacji Gorlickiej w działaniach wojennych I wojny światowej, materials of Międzynarodowej Sesji Naukowej, Gorlice 5-6.05.1995, Gorlice 1995; K. Bańburski, J. Kozioł, Wielka wojna: Tarnów-Gorlice 1915, Tarnów 2005.

61 B. Wójtowicz-Huber, op. cit., p. 231. siąca cywili. Ponadto dochodziło do samowolnych mordów prowadzonych przez żołnierzy (szczególnie brutalni byli Węgrzy), choćby 30 osób w Kuźminie, powieszenie w Turce przeszło 70, wreszcie zmasakrowanie przez żołnierzy węgierskich i tłum na ulicach Przemyśla konwoju aresztantów. W masakrze tej 15 sierpnia 1914 r. z 46 więźniów ocalały tylko 2 osoby ${ }^{59}$. Wszystko to działo się w poczuciu „ruskiej zdrady”, która to miała tłumaczyć olbrzymie postępy wojsk rosyjskich w Galicji i szybkie osiągnięcie grzbietu Karpat w tym Przełęczy Dukielskiej ${ }^{60}$.

Od 4 września 1916 r. do 17 lutego 1917 r. w Wiedniu toczył się już trzeci wielki proces rusofilów. Przed sądem stanęło 22 oskarżonych, w tym 10 z Galicji Zachodniej (Łemkowszczyzna), 9 ze Wschodniej a 3 z Bukowiny. 16 usłyszało wyrok śmierci, te nie zostały wykonane tylko ze względu na wstawiennictwo cara Mikołaja II. Skazanym zarzucono upowszechnianie idei rusofilskiej i dążenie do oderwania Galicji, Bukowiny i Zakarpacia od Austriii ${ }^{61}$.

59 T.A. Olszański, Austriackie represje w Galicji i obóz $w$ Thalerhofie, http://www.stowarzyszenielemkow.pl/new/modules/publisher/item.php?itemi$\mathrm{d}=100$ \&lang=polish [dostęp: 1.10.2016].

${ }^{60}$ A. Walc, Militarne i polityczne znaczenie Operacji Gorlickiej w działaniach wojennych I wojny światowej, materiały Międzynarodowej Sesji Naukowej, Gorlice, 5-6.05.1995, Gorlice 1995; K. Bańburski, J. Kozioł, Wielka wojna: Tarnów-Gorlice 1915, Tarnów 2005.

${ }^{61}$ B. Wójtowicz-Huber, op. cit., s. 231. 


\section{Consequences for Poland}

The first consequence of the strong Russophile movement among the Lemkos was the rise of the Ruthenian ${ }^{62}$ People's Republic (1918), which was created by Russophiles wishing to link it with Russia (including Jurchykevych, released in 1917) ${ }^{63}$. Russia was no longer as such, hence the idea of connecting with the compatriots on the southern side of the Carpathians appeared. This concerned the Polish authorities that carried out the pacification. Russophile moods were still very popular, and longing for Orthodoxy was not over. Because the Greek Catholic hierarchy, not only continued its policy, but even tightened it up, and this caused even greater opposition from the Lemkos, so it ended with the so-called "Tylawa schism" and mass conversions to Orthodoxy ${ }^{64}$. The Poles made significant use of it, and with the help of the Vatican there was a very profitable use of religious geopolitics. Almost all Lemkivshchyna was excluded from the jurisdiction of Przemysl and entered the Apostolic Administration of the Lemko region, thus separating the Lemkos from Ukrainian propaganda to a large extent. Russophilism

62 I.e. Russian.

63 See more: B. Horbal, Działalność polityczna Łemków na Łemkowszczyźnie, 1918-1921, Wrocław 1997; T.A. Olszański, Ruska Republika Ludowa Łemków. Nowe spojrzenie w przededniu osiemdziesiatej rocznicy, "Magury '98”, Warszawa 1998, pp. 25-36.

64 See more: A. Krochmal, Stosunki między grekokatolikami i prawosławnymi na Łemkowszczyźnie w latach 1918-1939, [in:] Eemkowie w historii i kulturze Karpat, edit. J. Czajkowski, vol. 1, Rzeszów 1992; B. Prach, Apostolska Administracja Łemkowszczyzny, [in:] Łemkowie w historii..., p. 301; S. Stępień, Życie religijne społeczności ukraińskiej w Drugiej Rzeczpospolitej, [in:] Polska-Ukraina 1000 lat sąsiedztwa, vol. 1, Studia $z$ dziejów chrześcijaństwa na pograniczu etnicznym, edit. S. Stępień, Przemyśl 1990, p. 216.

\section{Konsekwencje dlla Polski}

Pierwszą konsekwencją silnego ruchu rusofilskiego wśród Łemków było powstanie Ruskiej ${ }^{62}$ Republiki Ludowej (1918), która była tworzona przez rusofili pragnących jej połączenia z Rosją (w tym zwolniony w 1917 r. Jurczykewycz) ${ }^{63}$. Rosji już jednak jako takiej nie było, dlatego pojawił się pomysł połączenia z rodakami po południowej stronie Karpat. To zaniepokoiło polskie władze, które przeprowadziły pacyfikacje. Rusofilskie nastroje nadal miały się bardzo dobrze, a tęsknota do prawosławia nie minęła. Ponieważ hierarchia greckokatolicka, nie dość że kontynuowała swoją politykę, to nawet ją zaostrzała, co wywoływało jeszcze większy sprzeciw Łemków, a to zakończyło się tzw. schizmą tylawską i masowymi konwersjami na prawosławie ${ }^{64}$. Polacy to znakomicie wykorzystali i z pomocą Watykanu doszło do bardzo korzystnej zagrywki geopolityki religijnej. Praktycznie cała Łemkowszczyzna został wyłączona spod jurysdykcji Przemyśla i weszła w skład Apostolskiej Administracji Łemkowszczyzny, w ten sposób odizolowano

62 Czytaj: rosyjskiej.

63 Więcej: B. Horbal, Działalność polityczna Łemków na Łemkowszczyźnie, 1918-1921, Wrocław 1997; T.A. Olszański, Ruska Republika Ludowa Łemków. Nowe spojrzenie w przededniu osiemdziesiątej rocznicy, „Magury '98”, Warszawa 1998, s. 25-36.

64 Więcej: A. Krochmal, Stosunki między grekokatolikami i prawosławnymi na Łemkowszczyźnie w latach 1918-1939, [w:] Łemkowie w historii i kulturze Karpat, red. J. Czajkowski, cz. 1, Rzeszów 1992; B. Prach, Apostolska Administracja Łemkowszczyzny, [w:] Łemkowie w historii..., s. 301; S. Stępień, Życie religijne społeczności ukraińskiej w Drugiej Rzeczpospolitej, [w:] Polska - Ukraina 1000 lat sasiedztwa, t. 1, Studia z dziejów chrześcijaństwa na pograniczu etnicznym, red. S. Stępień, Przemyśl 1990, s. 216. 
had yet another meaning: the political one. These communities were eager to cooperate with the Polish authorities, and these were willing to make some concessions, as long as it kept the Lemkos far from the Ukrainians ${ }^{65}$. The best example is cooperation with BBWR (The Nonpartisan Bloc for Cooperation with the Government) and founding Lemko-Soyuz. Russophile, or at least, antiUkrainian attitudes and loyalty to the state, also resulted in cooperation with the Polish underground during the occupation. Right after it, the Lemko region was quite hostile to the Ukrainian Insurgent Army, which at first could not count on cooperation, recruitment, and even the Lemkos fought against the UPA by cooperating with the authorities. Living in such a geostrategic location, however, had a devastating effect on the Lemkos themselves. First Lemkivshchyna was severely destroyed during the First World War, mainly as a result of the so-called Gorlice battle. A large part of the population was repressed by the Austrians. In World War II, the Germans immediately "cleared" the passes by closing the Russophiles in Auschwitz and then interning on the eve of the Dukla offensive. But a very reasonable assumption appears that the strategic location of this place and the desire to secure the borders became one of the causes of another misfortune that was the "Vistula" operation. Considering that the Communists knew perfectly well the military significance and territorial claims of Khrushchev ${ }^{66}$, and also the ethnic structure, there is no question of mistake or hasty

\footnotetext{
65 See: J. Moklak, op. cit., pp. 181-183.

66 See: Z. Zaks, Stosunki polsko-radzieckie $w$ świetle francuskiej dokumentacji dyplomatycznej
}

w dużym stopniu Łemków od propagandy ukraińskiej. Rusofilizm miał jeszcze jedno znaczenie, polityczne. Te środowiska chętnie współpracowały z polskimi władzami, a te były chętne do pewnych ustępstw, tak długo jak pozostawiało to Łemków z dala od Ukraińców ${ }^{65}$. Takim najlepszym przykładem jest współpraca z BBWR i powstanie Łemko-Sojuza. Postawy rusofilskie, a w każdym razie antyukraińskie i lojalnościowe wobec państwa skutkowały też współpracą z polskim podziemiem w czasie okupacji. Tuż po niej z kolei Łemkowszczyzna była dość nieprzyjaznym terenem dla działań Ukraińskiej Powstańczej Armii, która w początkowym okresie nie mogła liczyć na współpracę, werbunek, a nawet często Łemkowie zwalczali UPA, współpracując z władzami. Zamieszkiwanie tak ważnego pod wzglądem geostrategicznym miejsca miało jednak dla samych Łemków zgubne skutki. Najpierw Łemkowszczyzna została poważnie zniszczona podczas I wojny światowej, głównie w wyniku tzw. bitwy gorlickiej, spora część ludności była represjonowana przez Austriaków. W II wojnie światowej Niemcy od razu „oczyścili” przełęcze, zamykając rusofilów w Auschwitz, a następnie internując w przededniu ofensywy dukielskiej. Ale powstaje bardzo uzasadnione przypuszczenie, że strategiczność tego miejsca i chęć zabezpieczenia granic stała się jedną z przyczyn kolejnego nieszczęścia jakim była akcja „Wisła”. Biorąc pod uwagę, że komuniści doskonale znali i znaczenie militarne, i roszczenia terytorialne

65 Por. J. Moklak, op. cit., s. 181-183. 
action. The "Vistula" operation was supervised by Władysław Gomułka (whom the Lemkos hid during the war), but also Ostap Steca, coming from Komańcza, a general of the Red and Polish Army. It can therefore be considered that an ethnic cleansing of the borderland from the non-Polish population (in this area also Gypsies were resettled) was in the geopolitical interest of Poland. Such a policy was not strange to the Communists. It is enough to recall the resettlement of Chechens (safeguarding the border with Iran) or the people of Crimea (Tatars, Greeks, Germans, etc.), of which effects are visible today. Let's be honest, Stalin ${ }^{67}$ by his "ethnic engineering" replaced the people of Crimea with the Russians, and the effect was apparent only recently when ethnically Russian Crimea returned without a single shot to Russia. It is difficult to expect, however, that in today's Poland there may still be some sort of aftermath of Rusyns' Russophilism, perhaps pro-Russian motives are rather the domain of the Polish nationalists referring to Roman Dmowski's ideology. Certainly, the consequence of Russophilism is the division of the contemporary Ruthenian society, of course, it is impossible to decide whether or not Russophilism contributed to the inability to develop only the Ukrainian identity. Or did Ukrainophilism not face friendly environment and Russophilism was the result of the unattractiveness of the Ukrainian offer and in fact gave the community a chance to look for another national identity. The Ukrainian en-

1944 roku [styczeń- lipiec 1944], „Dzieje Najnowsze”, No. 3, 1987, p. 122.

67 See: K. Grygajtis, Józef Stalin oraz sowiecka geopolityka i geostrategia lat 1924-1953, Nysa 2011.
Chruszczowa $^{66}$, jak i strukturę etniczną, nie ma mowy o pomyłce czy pochopnym działaniu. Akcję "Wisła” nadzorowali choćby Władysław Gomułka (którego Łemkowie ukrywali podczas wojny), jak i Ostap Steca, pochodzący z Komańczy generał Armii Czerwonej i Polskiej. Można zatem uznać, że w interesie geopolitycznym Polski było etniczne oczyszczenie terenu przygranicznego z ludności niepolskiej (w tej akacji przesiedlano też choćby Cyganów). Taka polityka nie była niczym dziwnym dla komunistów, wystarczy przypomnieć przesiedlenia Czeczenów (zabezpieczenie granicy z Iranem) czy ludności Krymu (Tatarów, Greków, Niemców itd.), czego skutki dostrzegalne są dzisiaj. Nie ma się co oszukiwać, Stalin ${ }^{67}$ przez swoją „inżynierię etniczną" wymienił ludność Krymu na Rosjan, a efekty tego było widać niedawno, gdy etnicznie rosyjski Krym bez jednego wystrzału wrócił do Rosji. Trudno jednak spodziewać się, by dzisiaj w Polsce można było jeszcze znaleźć jakieś pokłosie rusofilizmu Rusinów, ewentualne wątki prorosyjskie raczej są domeną polskiej endecji odwołującej się choćby do ideologii Romana Dmowskiego. Z całą pewnością konsekwencją rusofilizmu jest podział współczesnej społeczności Rusinów, oczywiście niemożliwe jest rozstrzygnięcie, czy to rusofilizm przyczynił się do niewykształcenia się wyłącznie tożsamości ukraińskiej, czy też ukrainofilizm

66 Por. Z. Zaks, Stosunki polsko-radzieckie $w$ świetle francuskiej dokumentacji dyplomatycznej 1944 roku (styczeń-lipiec 1944), „Dzieje Najnowsze” 1987, nr 3, s. 122.

67 Por. K. Grygajtis, Józef Stalin oraz sowiecka geopolityka i geostrategia lat 1924-1953, Nysa 2011. 
vironment, however, still believes that this current has had a destructive effect on the identity of today's Lemkos and is still dangerous. Thus, Bohdan Huk who on the pages of the "Łemkiwska storinka" accuses the activists of the Ruska Bursa of spreading Russophilism and anti-Ukrainian activities, in other words pro-Russian. He probably sees in this a "Putin's column" which is to hit Ukrainity ${ }^{68}$.

\section{Consequences for Ukraine}

As far as Stalin ethnically organized the south of Ukraine, its western boundaries did not undergo the same way and even he joined part of Bukovina to the USRR. As a result, quite a lot of ethnic confusion was created in Carpathian Ruthenia. The ethnic structure is very complex, $80 \%$ are Ukrainians $^{69}$, Hungarians 12\%, Romanians $(2.6 \%)$, Russians $(2.5 \%)$, Roma people (1.1\%), Slovaks (0.5\%), Germans (0.3), Belarussians (0.1\%), Jews (0.05\%), Poles $(0.04 \%)$, Moldavians $(0.04 \%)^{70}$. In Chernivtsi Oblast, about 50,000 inhabitants already have Romanian citizenship, 76\% of Hungarians live in Berehove region, and

68 Б. Гук, Росія: насильтвво чи вільний вибір $P y c(c)$ кой Бурси?, "Наше Слово” 2015, No. 20 (3014), p. 8.

69 And Rusyns, not included as a separate group.

70 I. Janina, Mały krok do Wielkich Wegier, http://www.kresy.pl/publicystyka,wydarzeniatygodnia?zobacz\%2Fmaly-krok-do-wielkich-wegier [access on: 1.10.2016]. nie trafił na podatny grunt i rusofilizm był wynikiem nieatrakcyjności oferty ukraińskiej i tak naprawdę dał tej społeczności szanse na poszukanie innej tożsamości narodowej. Środowiska ukraińskie jednak nadal uważają, że ten nurt miał destrukcyjny wpływ na tożsamość dzisiejszych Łemków i wciąż jest niebezpieczny. Tak widzi to choćby Bohdan Huk, który na stronach „Łemkiwskiej Storinki” zarzuca działaczom Ruskiej Bursy szerzenie rusofilstwa i działania antyukraińskie, czytaj prorosyjskie, widząc w tym zapewne jakąś „putinowską kolumnę” mającą uderzyć w ukraińskośćc8.

\section{Konsekwencje dla Ukrainy}

O ile Stalin etnicznie zorganizował południe Ukrainy, o tyle jej zachodnie kresy już nie przeszły tej samej drogi i tak włączył choćby część Bukowiny do USRR. W efekcie tego na Zakarpaciu powstało całkiem spore zamieszanie etniczne. Struktura etniczna jest tam mocno skomplikowana, 80\% stanowią Ukraińcy ${ }^{69}$, Węgrzy $12 \%$, ponadto Rumuni (2,6\%), Rosjanie $(2,5 \%)$, Romowie $(1,1 \%)$, Słowacy $(0,5 \%)$, Niemcy $(0,3 \%)$, Białorusini (0,1\%), Żydzi (0,05\%), Polacy (0,04\%), Mołdawianie $(0,04 \%)^{70}$. W obwodzie czerniowieckim obywatelstwo rumuńskie posiada już około 50 tys. mieszkańców, w re-

68 Б. Гук, Росія: насилььтво чи вільний вибір Рус(с)кой Бурси?, „Наше Слово” 2015, nr 20 (3014), s. 8.

${ }^{69} \mathrm{~W}$ tym Rusini, nieujęci jako osobna grupa.

70 I. Janina, Mały krok do Wielkich Wegier, http://www.kresy.pl/publicystyka,wydarzeniatygodnia?zobacz\%2Fmaly-krok-do-wielkich-wegier [dostęp: 1.10.2016]. 
the Hungarian national anthem is the official anthem of the local government.

The first Rusyn organizations in Ukraine appeared in the 1990s. It was among others the Society of Carpathian Rusyns, Alexander Duchnovych Association, Cyril and Methodius Society, and Ruthenian National Education Association. This first organization, on 29 August 1990, approved in Uzhgorod a "Declaration on the return of the Zakarpattia Oblast to the status of an autonomous republic", which was in line with the findings of Saint-Germain (1919) and Trianon (1920), at the same time the Firlinger-Molotov agreement $^{71}$ was declared invalid. On 1 September 1990, a manifestation was held in Mukachevo with the postulate of a plebiscite, and finally the authorities agreed on a referendum on the creation of a special self-government zone. In a referendum on 1 December 1991, with a turnout of $92 \%, 78 \%$ of the voters were "for", against $18.4 \%^{72}$. In June 1994, the Transcarpathian Rusyns Association established the Provisional Government for Carpathian Ruthe$\mathrm{nia}^{73}$, the main postulate was a plebiscite.

71 The agreement of June 29, 1945, which transferred Carpathian Ruthenia to the USRR, this was part of Czechoslovakia, as the third member of the federation (although not included in the name of the state), for a short time the Carpathian Ruthenia gained independence under the name of Carpathian Ukraine, see more: P.R. Magocsi, The Shaping of a National Identity Subcarpathian Rus', 1848-1948, London 1978, pp. 243 and following.

72 E. Michna, Kwestie etniczno-narodowościowe na pograniczu Słowiańszczyzny wschodniej i zachodniej: Ruch Rusiński na Stowacji, Ukrainie i Polsce, Kraków 2004, p. 115.

73 Domagamy się autonomii, Rozmowa z Tiborem Ondikem, ministrem spraw zagranicznych tymczasowego rządu Rusi Zakarpackiej, http://www.lemko.org/rzeczpospolita/rzeczpospolita9.htm [access jonie Berehowa mieszka 76\% Węgrów, a hymn tego państwa jest oficjalnym hymnem samorządu.

Pierwsze organizacje rusińskie na Ukrainie pojawily się już w 1990 r., było to m.in. Towarzystwo Rusinów Karpackich, Towarzystwo Aleksandra Duchnowycza, Towarzystwo Cyryla i Metoego i Rusińskie Towarzystwo Narodowo-Edukacyjne. Ta pierwsza organizacja 29 sierpnia $1990 \mathrm{r}$. zatwierdziła w Użhorodzie „Deklarację w sprawie powrotu Obwodu Zakarpackiego do statusu republiki autonomicznej", co było zgodne z ustaleniami z Saint-Germain (1919) i Trianon (1920), jednocześnie uznano układ Firlinger-Mołotow ${ }^{71}$ za nieważny. W Mukaczewie 1 września 1990 r. zorganizowano manifestację z postulatem rozpisania plebiscytu, ostatecznie władze zgodziły się na referendum w sprawie utworzenia specjalnej strefy samorządowej. W referendum 1 grudnia $1991 \mathrm{r}$., przy frekwencji $92 \%$, „za” było $78 \%$ głosujących, przeciwko $18,4 \%{ }^{72}$. W czerwcu 1994 r. Stowarzyszenie Rusinów Zakarpackich założyło Rząd Tymczasowy dla Rusi Podkarpackiej ${ }^{73}$, głównym postulatem było przeprowadzenie plebiscytu. Par-

71 Układ z 29 czerwca 1945 r. przekazujący Zakarpacie USRR, ta część wchodziła w skład Czechosłowacji jako trzeci człon federacji (choć nie ujęty w nazwie państwa), na krótko Ruś Zakarpacka uzyskała niepodległość pod nazwą Ukraina Karpacka, więcej P.R. Magocsi, The Shaping of a National Identity Subcarpathian Rus, 1848-1948, London 1978, s. 243 i n.

72 E. Michna, Kwestie etniczno-narodowościowe na pograniczu Słowiańszczyzny wschodniej i zachodniej. Ruch Rusiński na Słowacji, Ukrainie i Polsce, Kraków 2004, s. 115.

73 Domagamy się autonomii. Rozmowa z Tiborem Ondikem, ministrem spraw zagranicznych tymczasowego rzadu Rusi Zakarpackiej, http://www.lemko.org/rzeczpospolita/rzeczpospolita9.htm [dostęp: 
The Ukrainian Parliament unequivocally condemned this behavior as a manifestation of Ukrainophobia, and the Carpathian Rusyns were to conduct dangerous activities aimed at changing the borders of Ukraine, all for the Russian money and for the interests of Czechoslovakia, Poland and Hungary ${ }^{74}$. In 1996, the authorities published "The plan for the solution of the Ruthenians-Ukrainians problem", which assumed a series of actions aimed at agitating among the people on the assumption of national unity with Ukraine. They wanted to use propaganda, science and culture activities. On the basis of the weakening of the Ukrainian state in 2014, autonomy demands returned ${ }^{75}$. Hungarians also began discussions on the interests of their state and citizens. Hungarian Deputy Prime Minister Zsolt Semjén revealed that under the new law 750,000 people applied for Hungarian citizenship ${ }^{76}$, and head of the Prime Minister's Office Orban openly talked about the need to ensure the security of Hungarians in Carpathian Ruthenia ${ }^{77}$.

on: 1.10.2016], E. Michna says, it was in May 1993: E. Michna, op. cit., p. 115.

74 E. Michna, op. cit., p. 117.

75 A. Zapałowski, Wpływ konfliktu na Ukrainie na możliwą destabilizację granic w Europie Środkowo-Wschodniej, "Ante Portas - Studia nad Bezpieczeństwem” 2016, No. 1(6), p. 36.

76700 tysięcy kresowych Węgrów otrzymało już obywatelstwo Wegier, http://www.pch24.pl/kresy-pl--700-tysiecy-kresowych-wegrow-otrzymalo-juzobywatelstwo-wegier,37159,i.html\#ixzz4KyrfaDL9 [access on: 1.10.2016].

77 Szefkancelarii premiera Viktora Orbána: Nasz wywiad działa na rzecz obrony Węgrów na Ukrainie, http://www.kresy.pl/wydarzenia,spoleczenstwo?zobacz/szef-kancelarii-premiera-viktora-orbananasz-wywiad-dziala-na-rzecz-obrony-wegrow-naukrainie [access on: 1.10.2016]. lament Ukrainy jednoznacznie potępił takie postępowanie, uznając go za przejaw ukrainofobii, a Karpatorusini mieli prowadzić niebezpieczną działalność, zmierzającą do zmian granic Ukrainy, a wszystko to za rosyjskie pieniądze i w interesie Czechosłowacji, Polski i Węgier ${ }^{74}$. W 1996 r. władze opublikowały „Plan rozwiązania problemu Rusinów-Ukraińców", który zakładał wiele działań mających na celu agitację wśród ludności założeń jedności narodowej z Ukrainą, służyć temu miały działania propagandowe, naukowe i kulturalne. $\mathrm{Wy}$ korzystując osłabienie państwa ukraińskiego w 2014 r., powróciły żądania autono$\mathrm{mii}^{75}$. Również Węgry rozpoczęły dyskusję nad interesami swoimi i swoich obywateli, węgierski wicepremier Zsolt Semjén ujawnił, że na mocy nowej ustawy podania o przyznanie obywatelstwa Węgier złożyło 750 tys. osób ${ }^{76}$, a szef kancelarii premiera Orban otwarcie mówi o potrzebie zapewnienia bezpieczeństwa Węgrom na Zakarpaciu ${ }^{77}$.

Podejrzenia o inspiracje rosyjskie nie są całkiem bezpodstawne. Ruch Rusiński

1.10.2016]; E. Michna podaje, że nastąpiło to w maju 1993 r.: E. Michna, op. cit., s. 115.

74 E. Michna, op. cit., s. 117.

75 A. Zapałowski, Wpływ konfliktu na Ukrainie na możliwą destabilizację granic w Europie Środkowo-Wschodniej, „Ante Portas - Studia nad Bezpieczeństwem" 2016, nr 1(6), s. 36.

76700 tysięcy kresowych Węgrów otrzymało już obywatelstwo Wegier, http://www.pch24.pl/kresy-pl--700-tysiecy-kresowych-wegrow-otrzymalo-juzobywatelstwo-wegier,37159,i.html\#ixzz4KyrfaDL9 [dostęp: 1.10.2016].

77 Szef kancelarii premiera Viktora Orbána: Nasz wywiad działa na rzecz obrony Wegrów na Ukrainie, http://www.kresy.pl/wydarzenia,spoleczenstwo?zobacz/szef-kancelarii-premiera-viktora-orbananasz-wywiad-dziala-na-rzecz-obrony-wegrow-naukrainie [dostęp: 1.10.2016]. 
Suspicions of Russian inspirations are not entirely unfounded. The Ruthenian Movement is derived directly from the Russophile movement before World War $\mathrm{II}^{78}$. At the end of October 2014, they published "The Appeal of the Carpathian Rusyns to Vladimir Putin". The selfappointed community leaders asked the President of Russia to support their aspirations for independence and defense against "enslavement by the Galician aggressive fascism". Moscow helped Ruthenians to secure in the past, so it must do it again because of the "humanitarian catastrophe of the Ruthenian nation and all the inhabitants of Carpathian Ruthenia, which was caused with the Galician hands of the Nazis and local collaborators". The authors of the appeal called on Moscow to carry out "peace operation for a short period of time" in Carpathian Ruthenia and "restore the pre-Soviet status of the Republic of Carpathian Ruthenia". Moscow should also put pressure on Kiev to recognize the results of the referendum of 1991, in which most of the participants declared that "Carpathian Ruthenia is a special, self-governing territory and the entity governed by international law not incorporated in any current administrative-territorial entity"79. The bindings of the leaders of the autonomous movement are not exactly clear, for example, Dmytro Sydor, Orthodox priest from Uzhgorod (Ukrainian Orthodox Church Moscow Patriar-

78 At least it refers itself to it.

79 Zakarpacie, czyli o groźbie separatyzmu mafijnego, https://oaspl.org/2015/12/17/zakarpacie-czyli-o-grozbie-separatyzmu-mafijnego/ [access on: 1.10.2016]. wywodzi się wprost $\mathrm{z}$ ruchu rusofilskiego sprzed II wojny światowej ${ }^{78}$. Pod koniec października 2014 r. opublikowały one „Apel zakarpackich Rusinów do Władimira Putina". Samozwańczy liderzy wspólnoty prosili prezydenta Rosji o wsparcie ich niepodległościowych aspiracji i obronę przed „zniewoleniem przez agresywny galicyjski faszyzm". Moskwa pomogła Rusinom w przeszłości, więc musi to zrobić raz jeszcze z powodu „humanitarnej katastrofy narodu rusińskiego i wszystkich mieszkańców Zakarpacia, którą zgotowano rękami galicyjskich nazistów i lokalnych kolaborantów". Autorzy apelu wzywali Moskwę do przeprowadzenia "pokojowej operacji na krótki okres czasu" na Zakarpaciu i „przywrócenia przedsowieckiego statusu Republiki Rusi Zakarpackiej”. Moskwa powinna też naciskać na Kijów, żeby uznał wyniki referendum z 1991 r., w którym większość uczestniczących zadeklarowała, że „Zakarpacie jest specjalnym, samorządnym terytorium i podmiotem prawa międzynarodowego nie włączonym w żaden obecny terytorialno-administracyjny twór"79. Nie do końca też jasne są powiązania liderów ruchu autonomicznego, np. Dymitr Sidor, prawosławny duchowny z Użhorodu (Ukraińska Cerkiew Prawosławna Patriarchatu Moskiewskiego), były szef Stowarzyszenia Rusinów Karpackich i przewodniczący Sejmu Podkarpackich Rusinów jest podejrzany o przyjmowanie pieniędzy od Fundusz Politika, której sze-

78 A przynajmniej sam się do niego odwołuje.

79 Zakarpacie, czyli o groźbie separatyzmu mafijnego, https://oaspl.org/2015/12/17/zakarpacie-czyli-o-grozbie-separatyzmu-mafijnego/ [dostęp: 1.10.2016]. 
chate), the former head of the Society of Carpathian Rusyns and chairman of the Sejm of Carpathian Rusyns is suspected of accepting money from the Politika Fund, whose chief was Vyacheslav Nikon, since 2007 the head of "Russkij Mir"

Russia is interested in returning to Central Europe and leaving Hartland. For this they need Ukraine first, which they must destabilize, and then join or subordinate. With its natural resources, population and geostrategic position, Russia would be back in the game, the game for the empire ${ }^{81}$. Especially "foreign homeland"82 are helpful in this, the area where there are people who feel the same nationality, so in defense of the interests of these minorities one can try to intervene which Russia did in the Crimea, and to which the country claims rights $^{83}$. After the breakup of the USSR,

80 The Pan-Russian organization, Russkij Mir is not only ethnic Russians or Russian citizens, but also diaspora in "far and near abroad" countries, immigrants, Russian refugees, but also everyone, who is concerned about Russia's future, the organization was created by W. Putin, see more: A. Wierzbicki, op. cit., pp. 103-104.

81 See: A. Bryc, Wpływ geopolityki na tożsamość międzynarodowa Polski i Rosji, [in:] Geopolityka w stosunkach..., p. 39.

82 See more: R. Brubaker, Nacjonalizm inaczej. Struktura narodowa i kwestie narodowe w nowej Europie, Warszawa-Kraków 1998, pp. 71-74.

83 The Russian Federation reserves the right to "ensure intervening in neighboring countries in defense of its own citizens or even if the authorities of a neighboring country conduct a policy that is contrary to the interests of Russia", see: Komorowski po raz kolejny zwołuje RBN. Tym razem pan prezydent chce rozmawiać o doktrynie wojennej Rosji, http:// wpolityce.pl/polityka/237596-komorowski-po-razkolejny-zwoluje-rbn-tym-razem-pan-prezydentchce-rozmawiac-o-doktrynie-wojennej-rosji [access on: 1.10.216], and Doktryna Wojenna Federacji Rosyjskiej, https://www.bbn.gov.pl/ftp/dok/01/DoktrynaFederacjiRosyjskiej.pdf [access on: 1.10.2016]. fem był Wiaczesław Nikonow, od $2007 \mathrm{r}$. szef „Ruskiego Miru”80.

Rosja jest zainteresowana powrotem do Europy Środkowej i wyjściem z Hartlandu. Do tego potrzebna jest im najpierw Ukraina, którą musi zdestabilizować, a potem przyłączyć lub ponownie uzależnić. Wraz z jej bogactwami, ludnością i położeniem geostrategicznym Rosja wróciłaby do gry, gry o imperium ${ }^{81}$. Pomocne są w tym zwłaszcza „zagraniczne ojczyzny”"2, czyli tereny, gdzie są ludzie poczuwający się do takiej samej narodowości, w obronie interesów tych mniejszości można pozwolić sobie na interwencję, co Rosja zrobiła na Krymie, a do czego zapewnia sobie prawo $^{83}$. Po rozpadzie ZSRR Rosja przez długi czas odmawiała formalnego potwierdzenia granicy między oboma państwami, następnie zaś opóźniała jej delimitacje i de-

80 Organizacja panrosyjska Russki Mir to nie tylko etniczni Rosjanie czy obywatele rosyjscy, lecz również diaspora w krajach „dalekiej i bliskiej zagranicy”, emigranci, uchodźcy rosyjscy, ale i wszyscy zatroskani przyszłością Rosji; organizacja została utworzona przez W. Putina, więcej: A. Wierzbicki, op. cit., s. 103-104.

81 Por. A. Bryc, Wpływ geopolityki na tożsamość międzynarodowa Polski i Rosji, [w:] Geopolityka $w$ stosunkach..., s. 39.

82 Więcej: R. Brubaker, Nacjonalizm inaczej. Struktura narodowa i kwestie narodowe w nowej Europie, Warszawa-Kraków 1998, s. 71-74.

83 Federacja Rosyjska ,zapewnienia sobie [możliwość] interwencji w sąsiednich krajach w obronie własnych obywateli czy nawet w sytuacji, gdyby władze sąsiedniego kraju prowadziły politykę sprzeczna z interesami Rosji”, por. Komorowski po raz kolejny zwołuje RBN. Tym razem pan prezydent chce rozmawiać o doktrynie wojennej Rosji, http:// wpolityce.pl/polityka/237596-komorowski-po-razkolejny-zwoluje-rbn-tym-razem-pan-prezydentchce-rozmawiac-o-doktrynie-wojennej-rosji [dostęp: 1.10.216] oraz Doktryna Wojenna Federacji Rosyjskiej, https://www.bbn.gov.pl/ftp/dok/01/DoktrynaFederacjiRosyjskiej.pdf [dostęp: 1.10.2016]. 
Russia for a long time refused to formalize the border between the two countries, and in the end delayed its delimitation and demarcation. This was due to several reasons. Some elites had difficulty accepting new borders ${ }^{84}$ and believed that the present Ukraine included lands that never belonged to it: Crimea, the Donbas, and the southern Ukraine (so called Novorossiya). The unregulated status of the border was supposed to uphold the conviction of its temporary character in both societies. The border problem also hampers the development of Ukraine's cooperation with the European Union. This situation is in line with Russia’s interests ${ }^{85}$. Such "liquidation" of borders undermines Ukraine's position and even undermines its statehood ${ }^{86}$, and the fact is that Ukraine has largely lost control of this region. Examples are oligarchs fighting in the streets of Mukachevo ${ }^{87}$ or helplessness in sealing the border ${ }^{88}$.

It seems that the problems of the Carpathian Ruthenia minorities are quite exaggerated. They are, first of all, the result of the active policy of Russia and Hungary,

84 A. Sołżenicyn, Rosja w zapaści, Warszawa 1999 , p. 242.

85 A. Szeptycki, Ukraina wobec Rosji. Studium zależności, Warszawa 2013, p. 241.

86 See: G. Jellinek, Ogólna nauka o państwie, Vol. 1-2, Warszawa 1921.

87 Przemyt, Wegrzy i baron z Mukaczewa. O co naprawde chodzi na Zakarpaciu, http:// www.tvn24.pl/wiadomosci-ze-swiata,2/przemytwegrzy-i-baron-z-mukaczewa-o-co-chodzi-nazakarpaciu,560857.html [access on: 1.10.2016].

88 Gubernator Zakarpacia: poniosłem klęskę $w$ walce $z$ przemytnikami, rzad stracił kontrole nad przemytem, http://www.kresy.pl/wydarzenia,bezpieczenstwo-i-obrona?zobacz/gubernator-zakarpacia-ponioslem-kleske-w-walce-z-przemytnikamirzad-stracil-kontrole-nad-przemytem [access on: 1.10.2016]. markację. Taka postawa wynikała z kilku powodów. Część elit miała trudność z zaakceptowaniem nowych granic ${ }^{84}$ i uważała, że obecna Ukraina obejmuje ziemie, które nigdy do niej nie należały: chodziło w szczególności o Krym, Donbas i południową Ukrainę (tzw. Noworosję). Nieuregulowany status granicy miał podtrzymać w obu społeczeństwach przekonanie o jej tymczasowym charakterze. Problem graniczny utrudnia także rozwój współpracy Ukrainy z Unią Europejską; sytuacja taka jest zgodna $\mathrm{z}$ interesami Rosji ${ }^{85}$. Takie „upłynnienie” granic osłabia pozycję Ukrainy, a nawet podważa jej państwowośśc ${ }^{86}$, a faktem jest, że Ukraina w dużej mierze utraciła kontrolę nad tym rejonem. Przykładem są walki oligarchów na ulicach Mukaczewa ${ }^{87}$ czy bezradność w uszczelnianiu granicy ${ }^{88}$.

Wydaje się, że problemy mniejszości Zakarpacia są dość przesadzone, wynikają one po pierwsze $\mathrm{z}$ aktywnej polityki Rosji i Węgier, zarówno przed stu laty, jak i obecnie, pewnej ignorancji Kijowa i słabości państwa ukraińskiego. Rosja jest zainteresowana destabilizacją Ukra-

84 A. Sołżenicyn, Rosja w zapaści, Warszawa 1999, s. 242.

85 A. Szeptycki, Ukraina wobec Rosji. Studium zależności, Warszawa 2013, s. 241.

86 Por. G. Jellinek, Ogólna nauka o państwie, t. 1-2, Warszawa 1921

87 Przemyt, Wegrzy i baron z Mukaczewa. O co naprawdęchodzi na Zakarpaciu, http://www.tvn24.pl/ wiadomosci-ze-swiata,2/przemyt-wegrzy-i-baronz-mukaczewa-o-co-chodzi-na-zakarpaciu, 560857. html [dostęp: 1.10.2016].

88 Gubernator Zakarpacia: poniosłem klęskę $w$ walce $z$ przemytnikami, rząd stracit kontrole nad przemytem, http://www.kresy.pl/wydarzenia,bezpieczenstwo-i-obrona?zobacz/gubernator-zakarpaciaponioslem-kleske-w-walce-z-przemytnikami-rzadstracil-kontrole-nad-przemytem [dostęp: 1.10.2016]. 
just a hundred years ago and now, a certain ignorance of Kiev and the weakness of the Ukrainian state. Russia is interested in the destabilization of Ukraine, its leaky borders block the integration with the West, and so do the unsettled issues of national minorities. Moreover, in this area there is an important gas node, which also determines the policy of Moscow. And the states that are not in principle antagonistic towards Moscow, like Slovakia or Hungary their interests can also win their interests $^{89}$. However, the words of Vladimir Zhirinovsky give a lot to think:

These were the eastern Polish lands Lutsk, Lvov, Ternopol, Ivano-Frankivsk and Rivne. The Zakarpattia Oblast - it is Hungary. In Uzhgorod they all speak Hungarian. Or Russian. There is no connection with Ukraine. And Chernivtsi - in this case no agreement was made. Stalin took Chernivtsi to satisfy his appetite; There was no agreement with Hitler ${ }^{90}$.

\section{Abstract}

Rusophilism was an alternative for Carpathian Rusyns, including Lemkos, to Ukrainian nationalism. Russia used Interest in this ideology, for which the areas inhabited by Rusyns were geopolitically important. Positive attitude of this population could help to seize Central Europe and realize the imperial interests of Russia. The consequences are visible even today and are being used to destabilize the situation in Ukraine.

89 A. Zapałowski, Konsekwencje rozpadu Ukrainy dla bezpieczeństwa Unii Europejskiej, [in:] idem, Ukraina i Europ Wschodnia - geopolityczne wyzwania dla Polski i Rosji, Częstochowa 2014, p. 161.

90 Żyrinowski proponuje Polsce udział w rozbiorze Ukrainy. „Zachodnie ziemie sa bardziej polskie”, http:// www.tvn24.pl/wiadomosci-ze-swiata,2/zyrinowski-proponuje-polsce-udzial-w-rozbiorze-ukrainyzachodnie-ziemie-sa-bardziej-polskie,408953.html [access on: 1.10.2016]. iny, jej nieszczelne granice blokują integrację z Zachodem, nieuregulowane kwestie mniejszości narodowych również, ponadto w tym rejonie znajduje się ważny węzeł gazowy, co też determinuje politykę Moskwy. A swoje interesy mogą też ugrać państwa, które nie są z zasady antagonistyczne wobec Moskwy, jak Słowacja czy Węgry ${ }^{89}$. Niemniej słowa Władimira Żyrynowskiego dają dużo do myślenia:

To były polskie ziemie wschodnie - Łuck, Lwów, Tarnopol, Iwano-Frankowsk i Równe. Obwód zakarpacki - to Węgry. W Użhorodzie wszyscy mówią po węgiersku. Albo po rosyjsku. Nie ma żadnego związku z Ukrainą. I Czerniowce - w tym wypadku żadnego porozumienia nie było. Stalin zabrał Czerniowce dla zaspokojenia apetytu; porozumienia z Hitlerem nie było ${ }^{90}$.

\section{Abstrakt}

Rusofilizm był alternatywą dla Rusinów Karpackich, w tym Łemków dla ukraińskiego nacjonalizmu. Zainteresowanie tą ideologią wykorzystała Rosja, dla której tereny zamieszkałe przez Rusinów miały znaczenie geopolityczne. Przychylność tej ludności mogła ułatwić opanowanie Europy Środkowej i zrealizować imperialne zamiary Rosji. Konsekwencje tego są widoczne do dziś i wykorzystywane choćby do destabilizacji sytuacji na Ukrainie.

89 A. Zapałowski, Konsekwencje rozpadu Ukrainy dla bezpieczeństwa Unii Europejskiej, [w:] idem, Ukraina i Europ Wschodnia - geopolityczne wyzwania dla Polski i Rosji, Częstochowa 2014, s. 161.

90 Żyrinowski proponuje Polsce udział w rozbiorze Ukrainy. „Zachodnie ziemie sa bardziej polskie”, http:// www.tvn24.pl/wiadomosci-ze-swiata,2/zyrinowski-proponuje-polsce-udzial-w-rozbiorze-ukrainyzachodnie-ziemie-sa-bardziej-polskie,408953.html [dostęp: 1.10.2016]. 


\section{Bibliography / Bibliografia}

700 tysięcy kresowych Węgrów otrzymało już obywatelstwo Węgier, http://www.pch24.pl/kresypl--700-tysiecy-kresowych-wegrow-otrzymalo-juz-obywatelstwo-wegier,37159, i.html\#ixzz4KyrfaDL9 [access on: 1.10.2016].

Bakunin Bibliography, http://dwardmac.pitzer.edu/Anarchist_Archives/bakunin/Bakuninbiblio. html [access on: 1.10.2016].

Brubaker R., Nacjonalizm inaczej. Struktura narodowa i kwestie narodowe $w$ nowej Europie, Warszawa-Kraków 1998.

Bryc A., Wplyw geopolityki na tożsamość międzynarodowa Polski i Rosji, [in:] Geopolityka w stosunkach polsko-rosyjskch, edit. S. Bieleń, A. Skrzypek, Warszawa 2012.

Brzeziński Z., Wielka szachownica. Główne cele polityki amerykańskiej, Warszawa 1998.

CDIAL (Centralnyj derżawnyj istorycznyj archiw Ukrajiny u m. Lwowi), 146/4/122, NN.

Clausewitz C. von, O wojnie, Kraków 2006.

Curanovič A., Geopolityka religii w stosunkach polsko-rosyjskich, [in:] Geopolityka w stosunkach polsko-rosyjskch, edit. S. Bieleń, A. Skrzypek, Warszawa 2012.

Doktryna Wojenna Federacji Rosyjskiej, https://www.bbn.gov.pl/ftp/dok/01/DoktrynaFederacjiRosyjskiej.pdf [access on: 1.10.2016].

Domagamy się autonomii, Rozmowa $z$ Tiborem Ondikem, ministrem spraw zagranicznych tymczasowego rządu Rusi Zakarpackiej, http://www.lemko.org/rzeczpospolita/rzeczpospolita9. htm [access on: 1.10.2016].

Gołąbek B., Lew Gumilow i Aleksander Dugin. O dwóch obliczach Eurazjatyzmu w Rosji po 1991 roku, Kraków 2012.

Grygajtis K., Józef Stalin oraz sowiecka geopolityka i geostrategia lat 1924-1953, Nysa 2011.

Gubernator Zakarpacia: poniosłem klęskę $w$ walce z przemytnikami, rząd stracił kontrole nad przemytem, http://www.kresy.pl/wydarzenia,bezpieczenstwo-i-obrona?zobacz/gubernator-zakarpacia-ponioslem-kleske-w-walce-z-przemytnikami-rzad-stracil-kontrole-nad-przemytem [access on: 1.10.2016].

Helcer M., Historia Imperium Rosyjskiego, Warszawa 2000.

Heywood A., Ideologie polityczne. Wprowadzenie, Warszawa 2007.

Himka J.-P., Religion and Nationality in Western Ukraine: The Greek Catholic Church and the Ruthenian National Movement in Galicia, 1867-1900; Montreal-Kingston-Londyn 1999.

Horbal B., Działalność polityczna Łemków na Łemkowszczyźnie, 1918-1921, Wrocław 1997.

Huntington S., Zderzenie cywilizacji i nowy kształt ładu światowego, Warszawa 1997.

Janina I., Mały krok do Wielkich Wegier, http://www.kresy.pl/publicystyka,wydarzeniatygodnia?zobacz\%2Fmaly-krok-do-wielkich-wegier [access on: 1.10.2016].

Jellinek G., Ogólna nauka o państwie, t. 1-2, Warszawa 1921.

Lach Z., Skrzyp J., Geopolityka i geostrategia, Warszawa 2007.

Magocsi P.R., Old Ruthenianisam and Russophilism: A New Conceptual Framework for Analyzing National Ideologies in Late $19^{\text {th }}$ Century Eastern Galicia, [in:] Literature, Poetics, History, edit. P. Debreczeny, American Contributions to the Ninth International Congress of Slavists, Kiev 1983, Columbus 1983.

Magocsi P.R., The Shaping of a National Identity Subcarpathian Rus', 1848-1948, London 1978.

Massaka I., Eurazjatyzm. Z dziejów rosyjskiego misjonizmu, Wrocław 2001.

Mazur P., Sukcesu nurtu rusofilskiego i starorusińskiego wśród Łemków w kontekście teorii elit Vilfrefo Pareto, "Rocznik Ruskiej Bursy 2014”, Gorlice 2014.

Michna E., Kwestie etniczno-narodowościowe na pograniczu Słowiańszczyzny wschodniej i zachodniej, Ruch Rusiński na Słowacji, Ukrainie i Polsce, Kraków 2004.

Moczulski L., Geopolityka. Potęga w czasie i przestrzeni, Warszawa 1999. 
Moklak J., Łemkowszczyzna $w$ drugiej Rzeczpospolitej, zagadnienia polityczne i wyznaniowe, Kraków 1997.

Olszański T.A., Austriackie represje w Galicji i obóz w Thalerhofie, http://www.stowarzyszenielemkow.pl/new/modules/publisher/item.php?itemid=100\&lang=polish [access on: 1.10.2016].

Olszański T.A., Ruska Republika Ludowa Łemków. Nowe spojrzenie w przededniu osiemdziesiątej rocznicy, "Magury" '98, Warszawa 1998.

Partacz C., Od Badeniego do Potockiego Stosunki polsko-ukraińskie w Galicji w latach 188-1908, Toruń 1997.

Parucki Z., Geografia polityczna i wojenna, Warszawa 1979.

Protokół 48. posiedzenia Komisji Standaryzacji Nazw Geograficznych poza Granicami Rzeczypospolitej Polskiej, http://ksng.gugik.gov.pl/pliki/protokol_ksng/protokol_ksng-48_posiedzenie. pdf [access on: 1.10.2016].

Przemyt, Wegrzy i baron $z$ Mukaczewa. O co naprawdę chodzi na Zakarpaciu, http://www. tvn24.pl/wiadomosci-ze-swiata,2/przemyt-wegrzy-i-baron-z-mukaczewa-o-co-chodzi-nazakarpaciu,560857.html [access on: 1.10.2016].

Radzik R., Rosyjski imperializm wspólnotowy. Trójjedyny naród ruski w badaniach socjologicznych, Lublin 2016

Smith A.D., Nacjonalizm. Teoria, ideologia, historia, Warszawa 2007.

Sołżenicyn A., Rosja w zapaści, Warszawa 1999.

Sykulski L., Rola paradygmatu geopolitycznego w rozwoju neoeurazjanizmu we współczesnej Rosji, [in:] Między historią, literaturą a polityką, edit. T. Nodzyński, Częstochowa 2009.

Szef kancelarii premiera Viktora Orbána: Nasz wywiad działa na rzecz obrony Węgrów na Ukrainie, http://www.kresy.pl/wydarzenia,spoleczenstwo?zobacz/szef-kancelarii-premiera-viktoraorbana-nasz-wywiad-dziala-na-rzecz-obrony-wegrow-na-ukrainie [access on: 1.10.2016].

Szeptycki A., Ukraina wobec Rosji. Studium zależności, Warszawa 2013.

Walicki A., Idea narodu w polskiej myśli oświeceniowej, Warszawa 2000.

Walicki A., Rosja, katolicyzm i sprawa polska, Warszawa 2002.

Wereszycki H., Pod bertem Habsburgów. Zagadnienie narodowościowe, Kraków 1986.

Wierzbicki A., Nacjonalizm i geopolityka w Europie Wschodniej, [in:] Geopolityka w stosunkach polsko-rosyjskch, edit. S. Bieleń, A. Skrzypek, Warszawa 2012.

Wójtowicz-Huber B., Ojcowie narodu. Duchowieństwa greckokatolickie w ruchu narodowym Rusinów galicyjskich (1867-1918), Warszawa 2008.

Zakarpacie, czyli o groźbie separatyzmu mafijnego, https://oaspl.org/2015/12/17/zakarpacie-czyli-o-grozbie-separatyzmu-mafijnego/ [access on: 1.10.2016].

Zapałowski A., Konsekwencje rozpadu Ukrainy dla bezpieczeństwa Unii Europejskiej, [in:] idem, Ukraina i Europ Wschodnia - geopolityczne wyzwania dla Polski i Rosji, Częstochowa 2014.

Zapałowski A., Wpływ konfliktu na Ukrainie na możliwa destabilizacje granic w Europie Środkowo-Wschodniej, "Ante Portas - Studia nad Bezpieczeństwem” 2016, No. 1(6).

Żyrinowski proponuje Polsce udział w rozbiorze Ukrainy. "Zachodnie ziemie sa bardziej polskie", http://www.tvn24.pl/wiadomosci-ze-swiata,2/zyrinowski-proponuje-polsce-udzial-wrozbiorze-ukrainy-zachodnie-ziemie-sa-bardziej-polskie,408953.html [access on: 1.10.2016].

Гук Б., Росія: насильтвво чи вільний вибір Рус(с)кой Бурси?, “Наше Слово” 2015, No. 20 (3014).

Article submitted: 13.10.2016; article accepted: 10.01.2017 